\title{
RESEARCH
}

Open Access

\section{Individualized body bioelectrical impedance parameters in newly diagnosed cancer children}

Taira Teresa Batista Luna 1,2,3, Maraelys Morales González ${ }^{3}$, Manuel Verdecia Jarque ${ }^{4}$, Tamara Rubio González ${ }^{5}$, Soraida Candida Acosta Brooks ${ }^{6}$, Antonio Rafael Selva Castañeda ${ }^{7}$, Justa Carmen Columbié Regüeiferos ${ }^{8}$, Victoriano Gustavo Sierra González ${ }^{9}$ and Luis Enrique Bergues Cabrales ${ }^{10^{*}}$ (D)

\begin{abstract}
Background: The bioelectric impedance analysis permits to estimate electrical parameters and body composition of subjects who are either apparently healthy or sick with different pathologies. The aim of this study is to individualize the analysis of body bioelectrical impedance parameters in newly diagnosed cancer children, by means of the bioelectrical impedance analysis for each age group, gender and cancer histological variety.

Methods: This retrospective cross-sectional study consisted of 43 pediatric patients with different histological varieties of cancer, ages from 2 to 17. The body electrical resistance and body capacitive electrical reactance were measured with the Bodystat 1500-MDD analyzer. From these two electrical parameters the body electrical impedance modulus and the body phase angle were calculated.

Results: The results showed that $93.02 \%$ of cancer children were outside reference rectangles according to age groups and gender were showed. The values of body capacitive electrical reactance (72.5\%) and body phase angle (90.70\%) of these patients were below the lower limits of their respective rectangles. These findings were noticeable for patients who had solid tumors.

Conclusions: The BIA is feasible to individualize body bioelectrical parameters and body bioelectric state in newly diagnosed cancer children and how differ from those in apparently healthy subjects, for the same age group and gender. Additionally, the tumor electrical properties may have a noticeable role in changes of body bioelectricphysiological parameters of these newly diagnosed cancer children.
\end{abstract}

Keywords: Bodystat 1500-MDD analyzer, Body electrical resistance, Body capacitive electrical reactance, Body phase angle, Bioelectrical impedance analysis, Newly diagnosed cancer children

\footnotetext{
* Correspondence: berguesc@yahoo.com

${ }^{10}$ Departamento de Investigaciones, Centro Nacional de Electromagnetismo Aplicado, Universidad de Oriente, Ave. Las Américas s/n, 90400 Santiago de Cuba, Cuba

Full list of author information is available at the end of the article
}

(c) The Author(s). 2020 Open Access This article is licensed under a Creative Commons Attribution 4.0 International License, which permits use, sharing, adaptation, distribution and reproduction in any medium or format, as long as you give appropriate credit to the original author(s) and the source, provide a link to the Creative Commons licence, and indicate if changes were made. The images or other third party material in this article are included in the article's Creative Commons licence, unless indicated otherwise in a credit line to the material. If material is not included in the article's Creative Commons licence and your intended use is not permitted by statutory regulation or exceeds the permitted use, you will need to obtain permission directly from the copyright holder. To view a copy of this licence, visit http://creativecommons.org/licenses/by/4.0/. 


\section{Highlights}

- Body bioelectrical impedance parameters in newly diagnosed cancer children.

- Body electrical capacity of the patient and net electrical capacity of the tumor in newly diagnosed cancer children.

- Total electrical capacity of the healthy tissue and overall electrical capacity of the surrounding healthy tissue-tumor interface in newly diagnosed cancer children.

- Rectangular tolerance regions.

\section{Background}

The malignant tumor is the second cause of morbidity and mortality in Cuba and worldwide. The number of cancer patients is expected to increase progressively in the next years [1]. In Cuba, cancer is the first cause of death for patients ages 5 to 15 and the second cause of death in children between 1 and 4 years old [2]. These statistics are similar to those reported in other countries [1]. Around 400 children are diagnosed each year in Cuba and 35 of them correspond approximately to Santiago de Cuba province. This number has increased to 60 in the last triennium [2]. Acute lymphoblastic leukemia, central nervous system tumors, lymphomas, bone tumors and renal tumors are the most common malignant neoplasms in pediatric patients (1-18 years old) [2-4].

Cancer in pediatric patients can be diagnosed by clinical method and laboratory, pathologic and imaging tests [5]. Additionally, electrical impedance tomography, diffusion tensor magnetic resonance imaging, magnetic resonance electrical impedance tomography, magnetic induction tomography, magnetoacoustic tomography, Hall effect imaging and magnetoacoustic tomography with magnetic induction techniques have been suggested to electrically differentiate cancer from its surrounding healthy tissue based on differences between their electrical properties [6]. Tissue electrical properties have also been used to estimate the body composition, body water, among others in subjects who are either apparently healthy or sick with different pathologies by means of the bioelectric impedance analysis (BIA) $[7,8]$.

The BIA permits the estimation of different body bioelectric parameters, such as the body electrical resistance (R), body capacitive electrical reactance (Xc), body electrical impedance modulus $(|\mathrm{Z}|)$ and body phase angle $(\theta)$. Parameters R and Xc have been related to the body hydration status and body cell mass of subjects who are either apparently healthy or sick with different pathologies. These relationships have been established by means of different estimation equations [9-12]. The parameter $\theta$ is associated with the pathology severity and the quality of life, survival and prognosis of the evolution of a patient [8, 13-15]. In addition, BIA has been used to establish the normal intervals (means \pm standard deviations) of $\mathrm{R}, \mathrm{R} / \mathrm{H}, \mathrm{Xc}, \mathrm{Xc} / \mathrm{H}$ and $\theta$ of different populations of apparently healthy subjects in different countries $[16$, 17]. The variables $\mathrm{H}, \mathrm{R} / \mathrm{H}$ and $\mathrm{Xc} / \mathrm{H}$ are the height of the subject, the body electrical resistance per unit of height and the body capacitive electrical reactance per unit of height, respectively.

Normal intervals of $\mathrm{R} / \mathrm{H}, \mathrm{Xc} / \mathrm{H}$ and $\theta$ for a population of apparently healthy subjects of Santiago de Cuba, Cuba, by gender and age groups (2-80) are reported in [16]. For this, the BioScan 98 BIA analyzer (Biológica Tecnología Médica SL, Barcelona, Spain, available at http://www.blbiologico.es) is used. In addition, the Bland-Altman statistical method is used to assess the agreement between the BioScan 98 BIA analyzer and the Bodystat 1500-MDD BIA analyzer (Bodystat Firm Inc., Tampa, Florida, USA, available at http://www.bodystat.com) [18], as suggested in other studies [19, 20]. Values of R, Xc and $\theta$ generated with two devices are equals when correction factors for $\mathrm{R}$ and Xc are introduced in the BioScan $98(+14.7 \Omega$ for $\mathrm{R}$ and $+22 \Omega$ for Xc) and Bodystat 1500 MDD $(-3 \Omega$ for R and $+9 \Omega$ for Xc) BIA analyzers, as demonstrated in [18]. Consequently, these two BIA analyzers may be suitable in clinics. When the corrected and uncorrected R and Xc values are entered in any of total body water estimation equations, non-significant differences are reported from the statistical and clinical points of view [21]. This finding has been also observed for the fat free mass when the corrected and uncorrected $\mathrm{R}$ and Xc values are introduced in each one their estimation equations [22]. In these two studies, both BioScan 98 and Bodystat 1500-MDD BIA analyzers are used to estimate these values of $\mathrm{R}$ and Xc.

It is well documented in the literature that the bivariate analysis is one of the simplest forms of statistical analysis. It consists of the relationships between pairs of variables in a data set. This bivariate analysis usually involves the variables $X$ and $Y[23,24]$. Bivariate statistics has been extended to different problems of the science [25], specifically in the area of the bioelectrical impedance, known as the bioelectrical impedance vector analysis (BIVA). Piccoli is a pioneer of BIVA method [8, 26-28].

In BIVA plot, the variables $\mathrm{X}$ and $\mathrm{Y}$ are $\mathrm{R} / \mathrm{H}(\mathrm{R})$ and $\mathrm{Xc} / \mathrm{H}(\mathrm{Xc})$, respectively. Additionally, the reference intervals for any individual are represented in BIVA plots as 50, 75 and $95 \%$ tolerance ellipses obtained from apparently healthy population $[8,28]$. This idea has been extended to other BIA studies [16, 29, 30].

BIVA method is valid if the variables $\mathrm{R} / \mathrm{H}$ and $\mathrm{Xc} / \mathrm{H}$ ( $\mathrm{R}$ and $\mathrm{Xc}$ ) are highly correlated, as reported in previous studies [8, 23, 26-29]. In medicine, correlation strength has been classified in perfect $\left(r^{\prime \prime}=1.0\right)$, very strong $(0.8<$ $\left.\mathrm{r}^{\prime \prime}<0.9\right)$, moderate $\left(0.6<\mathrm{r}^{\prime \prime}<0.7\right)$, fair $\left(0.3<\mathrm{r}^{\prime \prime}<0.5\right)$, poor $\left(0.1<r^{\prime \prime}<0.2\right)$ and none $\left(r^{* \prime}=0.0\right)$, where $r^{\prime \prime}$ is the correlation coefficient of Pearson [31]. 
Although BIA has been used in pediatric patients with cancer [14, 32-35], we are not aware of its use to differentiate bioelectric parameters of newly diagnosed cancer children or untreated cancer children with those of apparently healthy population, by gender, age group and cancer type. The aim of this study is to individualize the analysis of body bioelectrical impedance parameters in newly diagnosed cancer children, by means of the bioelectrical impedance analysis for each age group, gender and cancer histological variety. Values of $\mathrm{R} / \mathrm{H}, \mathrm{Xc} / \mathrm{H}$ and $\theta$ of patients with solid tumor (Ts) and non-solid tumor (Tns) are compared with those estimated in apparently healthy pediatric subjects reported in [16].

\section{Methods}

\section{General characteristics of the research}

The retrospective clinical research was cross-sectional and carried out in the Oncology and Hematology department of the hospital Infantil Sur Antonio María Béguez César, Santiago de Cuba, Cuba. The research period lasted one year (7 September 2009-10 September 2010).

\section{Ethical considerations}

This retrospective clinical research was ruled by the ethical standards of the World Medical Association Declaration of Helsinki [36]. It was authorized by the Oncology and Hematology department and approved by the Ethics Committee (Current Controlled trials BIACANCER12032009, 12 March 2009) and Scientific Board of the hospital Infantil Sur Antonio María Béguez César, Santiago de Cuba. This trial registry was conserved in the Teaching Vice-direction of this hospital. The date of enrolment of the first participant to the trial was 07 September 2009. Additionally, the code of ethics, good medical practices and good clinical practices established by the Health General Law of the Ministry of Public Health of Republic of Cuba (Number 41, 13 July 1983 and updated in 2010) were taken into account in this research.

Pediatric patients were included in this research once their carers (parents, family or person in custody) read, agreed and signed the written Informed Consent. This written Informed Consent was signed by the parent/ guardian, medical oncologist and a psychologist (as a witness). It is important to note that prior to the signing of the written Informed Consent, aims, importance and purposes of this investigation were explained to carers, as well as all requirements for the measurements. These requirements were empty bladder, $12 \mathrm{~h}$ of fasting and $12 \mathrm{~h}$ of no physical exercises before measurements.

\section{Sample characteristics}

The inclusion criteria were the free consent of carers, the children with cancer at any stage confirmed by pathological anatomy and oncological patients at the
Oncology and Hematology department in the Hospital Infantil Sur Antonio María Béguez César. The exclusion criteria were carers/patients who did not wish to participate in the research and/or children had significant alterations, such as amputees, with generalized skin diseases, serious infections, symptomatic congestive heart failure, body fluid disorders and hemostatic. The interruption criteria were voluntary abandonment and death of the cancer patient.

The sample consisted of 43 untreated cancer children, ages 2 to 17. These patients were divided into two experimental groups. The first formed by 25 patients with different histological varieties of Ts and the second consisted of 18 patients with various types of Tns. The individual analysis of each patient was performed by each age group and gender, taking into account [16]. Each patient was assigned a numerical code from 1 to 43 .

\section{Measurement procedure with the Bodystat 1500-MDD BIA analyzer}

The Bodystat 1500-MDD BIA analyzer was used to estimate $R$ (in $\Omega$ ) and $X_{c}$ (in $\Omega$ ) in patients with Ts and Tns. Values of $|\mathrm{Z}|$ (in $\Omega$ ) and $\theta$ (in ${ }^{\circ}$ ) were calculated from $\mathrm{R}$ and $\mathrm{Xc}$, using the expressions and $\theta=\operatorname{tg}^{-1}(X c / R)$, respectively. In this study, $|\mathrm{Z}|$ was not reported because its values were similar to those of $R$ and their contributions on $\theta$ were also comparable. Maximum difference between $R$ and $|Z|$ values in cancer patients was $\leq 3 \Omega$. Additionally, maximum difference between $\theta$ values was $\leq 0.01^{\circ}$ when $\mathrm{R}$ and $|\mathrm{Z}|$ are considered on the mathematical expression for $\theta$. These differences had no significance in the clinical order, as in [18, 21, 22].

Although this device operated at frequencies of 5 and $50 \mathrm{kHz}$, the body values of $\mathrm{R}, \mathrm{Xc},|\mathrm{Z}|$ and $\theta$ were reported only at $50 \mathrm{kHz}$. The amplitude of the sinusoidal electric current applied was $800 \mu \mathrm{A}$. Additionally, the calibrator $(500.0 \pm 0.1 \Omega)$ was supplied by the manufacturer of the Bodystat 1500-MDD BIA analyzer and used to assess the stability of this device at the beginning and at the end of measurement in each patient.

This study was governed by the same methodology established in $[18,21,22]$ and recommendations established by the National Institutes of Health Technology Assessment Conference Statement for the measurement of bioelectrical parameters [37]. For the measurement of $R_{p}$ and $\mathrm{Xc}_{\mathrm{p}}$ values (the subscript $\mathrm{p}$ was referred to the cancer patient), the following methodology was followed [18, 21, 22 ]. First, $H$ and the weight of cancer patient were measured with a medical mechanical scale with stadiometer (model ZT-120, Zheiang, China) of accuracy \pm 0.1 . The minimum value of weight per division was $0.5 \mathrm{Kg}$ and the minimum value height per division was $0.5 \mathrm{~cm}$.

Second, patients covered with light clothing were placed in the supine position on a non-conductive surface, without 
a pillow under the head, with the arms separated at approximately $30^{\circ}$ from the thorax and the legs separated approximately at an angle of $45^{\circ}$ without contact between them. The skin of each patient was first cleaned with water and soap, and then $70 \%$ alcohol.

Third, the stimulating electrodes (or injection electrodes of alternating electric current) were placed in the medial areas of the dorsal surfaces of hands and feet, near the metacarpal and metatarsal phalangeal joints, respectively. The sensing electrodes (or receiving electrodes the body electrical voltage) were placed between the distal epiphyses of the radius and the ulna, at the level of the pisiform eminence, as well as at the midpoint between both malleoli, respectively. The distance between the sensing and stimulating electrodes was $5 \mathrm{~cm}$ and measured with a standard measuring tape (Lotus model, Ningbo Sunshine Company, Ningbo, China) of $0.1 \mathrm{~cm}$ precision. Electrocardiogram electrodes (model APR-020, All Pro Corporation Company, Quingdao, China) were used. The material of each electrode was Silver/Silver Chloride (Ag/AgCl).

Fourth, $\mathrm{R}_{\mathrm{p}}$ and $\mathrm{Xc}_{\mathrm{p}}$ measurements were carried out in controlled environmental conditions of temperature $\left(25.0 \pm 1.0^{\circ} \mathrm{C}\right.$ ), relative humidity (60 to $\left.65 \%\right)$ and free environment of devices generating field and electromagnetic radiation. These two physical quantities were measured with a digital humidity and relative temperature meter Testo (model 608-H1, Shanghai, China). The accuracy of this instrument was $\pm 0.5^{\circ} \mathrm{C}$ and $\pm 3 \%$ for temperature and relative humidity, respectively. In addition, $R_{p}$ and $X_{c}$ measurements in each patient were between 8 and $9 \mathrm{am}$, by a previously trained nurse.

\section{Comparison between apparently healthy and sick subjects}

Average values of $(R / H)_{r},(X c / H)_{r}$ and $\theta_{r}$ were taken as references. This was argued because BioScan 98 and Bodystat 1500-MDD BIA analyzers were electrically equivalent, as demonstrated in [18]. The subscript $r$ was referred to the apparently healthy subjects. This population was used as reference. The means \pm 2 standard deviations of $(R / H)_{r}$, $(\mathrm{Xc} / \mathrm{H})_{\mathrm{r}}$ and $\theta_{\mathrm{r}}$ of apparently healthy children by age group and gender were reported in [16]. These ranges were displayed in Table 1 to facilitate the reading of this study. Data shown in this table were provided by MSc. Alcibiades Lara Lafargue (researcher in charge of the population study in apparently healthy subjects). The latter was conducted at the Centro Nacional de Electromagnetismo Aplicado, Universidad de Oriente in Santiago de Cuba, Cuba (this institution will keep the original data of this population study for 15 years, according to the regulations established by the Ministry of Public Health of the Republic of Cuba).

The interval 17-59 was added in this study because a cancer infant was 17 years old (Table 1$).(\mathrm{R} / \mathrm{H})_{\mathrm{p}}$ and $(\mathrm{R} /$ $\mathrm{H})_{\mathrm{r}},(\mathrm{Xc} / \mathrm{H})_{\mathrm{p}}$ and $(\mathrm{Xc} / \mathrm{H})_{\mathrm{r}}$, and $\theta_{\mathrm{p}}$ and $\theta_{\mathrm{r}}$ were compared.
Table 1 Means \pm 2 standard deviations of bioelectric parameters per height unit for apparently healthy pediatric individuals, by gender and age group

\begin{tabular}{|c|c|c|c|c|c|}
\hline $\begin{array}{l}\text { Age group } \\
\text { (years) }\end{array}$ & Gender & $\begin{array}{l}(\mathrm{R} / \mathrm{H})_{\mathrm{r}} \\
(\Omega / \mathrm{m})\end{array}$ & $\begin{array}{l}(\mathrm{Xc} / \mathrm{H})_{\mathrm{r}} \\
(\Omega / \mathrm{m})\end{array}$ & $\begin{array}{l}\theta_{\mathrm{r}} \\
\left({ }^{\circ}\right)\end{array}$ & $r(R, X$ \\
\hline $2-3$ & $M, F(N=61)$ & $741.4 \pm 79.2$ & $70.9 \pm 8.1$ & $5.5 \pm 0.5$ & 0.67 \\
\hline $4-5$ & $M, F(N=91)$ & $651.2 \pm 65.6$ & $63.2 \pm 6.4$ & $5.6 \pm 0.5$ & 0.55 \\
\hline $6-7$ & $M, F(N=165)$ & $578.5 \pm 52.4$ & $57.5 \pm 6.3$ & $5.7 \pm 0.5$ & 0.60 \\
\hline $8-9$ & $M, F(N=179)$ & $513.0 \pm 51.1$ & $51.0 \pm 5.2$ & $5.7 \pm 0.4$ & 0.67 \\
\hline $10-11$ & $M, F(N=196)$ & $461.3 \pm 59.6$ & $47.0 \pm 5.9$ & $5.8 \pm 0.6$ & 0.59 \\
\hline 12 & $M, F(N=109)$ & $419.6 \pm 50.8$ & $43.6 \pm 5.0$ & $5.9 \pm 0.5$ & 0.71 \\
\hline \multirow[t]{2}{*}{$13-16$} & $M(N=101)$ & $335.2 \pm 48.7$ & $37.0 \pm 4.9$ & $6.3 \pm 0.5$ & 0.71 \\
\hline & $F(N=161)$ & $413.0 \pm 45.8$ & $43.6 \pm 4.7$ & $6.1 \pm 0.5$ & 0.69 \\
\hline \multirow[t]{2}{*}{$17-59$} & $M(N=1263)$ & $292.3 \pm 45.8$ & $33.8 \pm 3.6$ & $6.6 \pm 0.5$ & 0.72 \\
\hline & $F(N=1399)$ & $398.0 \pm 46.8$ & $42.0 \pm 5.2$ & $6.0 \pm 0.5$ & 0.71 \\
\hline
\end{tabular}

Height, male gender and female gender were represented by $H, M$ and $F$, respectively. $(R / H)_{r},(X C / H)_{r}, \theta_{r}$ and $r(R, X c)_{r}\left(r(R, X c)_{r}=r^{*}\right)$ were body electrical resistance/height, body capacitive electric reactance/height, body phase angle and correlation coefficient of Pearson, respectively [16] (courtesy of MSc. Alcibiade Lara Lafargue and Centro Nacional de Electromagnetismo Aplicado)

This comparison allowed us to know if a population of pediatric patients with cancer differed from that of the apparently healthy subjects, for each age group, gender and experimental group.

Since the $\mathrm{Xc} / \mathrm{H}$ versus $\mathrm{R} / \mathrm{H}$ plot was a twodimensional Euclidean space, the ordered pair $(\mathrm{R} / \mathrm{H}, \mathrm{Xc} /$ $\mathrm{H})$ was interpreted as the body bioelectric state of any subject from the bioelectrical point of view. In this study, body bioelectric states of the apparently healthy subject were represented by the ordered pair $\left((\mathrm{R} / \mathrm{H})_{\mathrm{r}},(\mathrm{Xc} / \mathrm{H})_{\mathrm{r}}\right)$. Body bioelectric states of the patient with Ts/Tns were denoted by the ordered pair $\left((\mathrm{R} / \mathrm{H})_{\mathrm{p}},(\mathrm{Xc} / \mathrm{H})_{\mathrm{p}}\right)$. Additionally, the body bioelectric state of each apparently healthy subject could be symbolized by the ordered pair $\left(R_{r}\right.$, $\mathrm{Xc}_{\mathrm{r}}$ ). The body bioelectric state of each untreated cancer pediatric patient could be represented by the ordered pair $\left(\mathrm{R}_{\mathrm{r}}, \mathrm{Xc}_{\mathrm{r}}\right)$. These two later asseverations were argued because the measurement was made in the same subject.

\section{Statistical analysis}

Spearman's rank correlation coefficient (or Spearman's rho) and Pearson correlation were used to know the lineal correlation between two variables: $R_{p}$ and $X c_{p},(R / H)_{p}$ and $(\mathrm{Xc} / \mathrm{H})_{\mathrm{p}}, \theta_{\mathrm{p}}$ and $\mathrm{R}_{\mathrm{p}}, \theta_{\mathrm{p}}$ and $\mathrm{Xc}_{\mathrm{p}}, \theta_{\mathrm{p}}$ and $(\mathrm{R} / \mathrm{H})_{\mathrm{p}}$, and $\theta_{\mathrm{p}}$ and $(\mathrm{Xc} / \mathrm{H})_{\mathrm{p}}$ for the solid and non-solid tumors. Probability $(p-$ value) was associated to each correlation analysis. Lineal correlation was significant when $p<0.05$ (significance level).

\section{Euclidean distance}

The Euclidean distance, named $\mathrm{d}_{\mathrm{pr}}(\Omega / \mathrm{m})$, between two points $\left((\mathrm{R} / \mathrm{H})_{\mathrm{p}},(\mathrm{Xc} / \mathrm{H})_{\mathrm{p}}\right)$ and $\left((\mathrm{R} / \mathrm{H})_{\mathrm{r}},(\mathrm{Xc} / \mathrm{H})_{\mathrm{r}}\right)$ was calculated by means of the following equation 


$$
d_{p r}=\sqrt{\left[\left(\frac{R}{H}\right)_{p}-\left(\frac{R}{H}\right)_{r}\right]^{2}+\left[\left(\frac{X c}{H}\right)_{p}-\left(\frac{X c}{H}\right)_{r}\right]^{2}}
$$

In eq. (1), $d_{p r}$ was calculated taking into account the gender, age and experimental group.

As $\left((\mathrm{R} / \mathrm{H})_{\mathrm{r}},(\mathrm{Xc} / \mathrm{H})_{\mathrm{r}}\right)$ represented the central point of the reference rectangle and $\left((\mathrm{R} / \mathrm{H})_{\mathrm{p}},(\mathrm{Xc} / \mathrm{H})_{\mathrm{p}}\right)$ the bioelectrical state of any cancer child for each gender and age group, their impedance vectors referred to coordinate origin $(0,0)$ were $\vec{Z}_{r}$ and $\vec{Z}_{p}$, respectively. Consequently, $\vec{Z}_{r}$ and $\vec{Z}_{p}$ were position vectors. Their respective modules were $\vec{Z}_{r}$ and $\vec{Z}_{p}$. It is important to point out that $\mathrm{d}_{\mathrm{pr}}$ should not be confused with $\vec{Z}_{r}$ and $\vec{Z}_{p} \cdot \mathrm{d}_{\mathrm{pr}}$ was the modulus of the difference between $\vec{Z}_{r}$ and $\quad \vec{Z}_{p}$, given by $\quad d_{p r}=\left|\vec{Z}_{p}-\vec{Z}_{r}\right|=$ $\left[\left|\vec{Z}_{r}\right|^{2}+\left|\vec{Z}_{p}\right|^{2}-2\left|\vec{Z}_{r} \| \vec{Z}_{p}\right| \cos \left(\vec{Z}_{p}, \vec{Z}_{r}\right)\right]^{1 / 2}$, where $\cos ($ $\left.\vec{Z}_{r}, \vec{Z}_{p}\right)=\vec{Z}_{r} \vec{Z}_{p} /\left|\vec{Z}_{r} \| \vec{Z}_{p}\right|$. It should be noted that the angle between $\vec{Z}_{r}$ and $\vec{Z}_{p}$ did not coincide with $\theta_{\mathrm{r}}$ or $\theta_{\mathrm{p}}$. It was demonstrated that $\cos \left(\vec{Z}_{r}, \vec{Z}_{p}\right)=\vec{Z}_{r} \vec{Z}_{p} / \mid \vec{Z}_{r}$ $\| \vec{Z}_{p} \mid .=\mathrm{r}[23]$.

From the mathematical point of view, $d_{\text {pr }}$ denoted the ordinary distance between two points in the plane Xc/ $H-R / H$. Nevertheless, from the bioelectric point of view, $\mathrm{d}_{\mathrm{pr}}$ meant how different the body bioelectric state of a cancer child was with respect to that of a reference population, for the same age group and gender. In other words, $d_{p r}$ was a measure of how the body bioelectric state of pediatric patient was affected by the presence of Ts/Tns. From the biophysical-chemical-energetic-clinical points of view, an increase in $d_{p r}$ was related to a greater degradation, smaller survival and quality of life of newly diagnosed cancer children. As $d_{p r}$ was reported for the first time in the literature, a scale for $\mathrm{d}_{\mathrm{pr}}$ was suggested: $1-50$; 51-100; 101-150; 151-200; 201-250; 251-300; 301-350 and $>350 \Omega / \mathrm{m}$, assuming that $d_{p r} \geq 50 \Omega / m$ could have significant implications on the body bioelectric state of a cancer patient. The case of $d_{p r}=0$ corresponded to the apparently healthy subject.

\section{Information processing}

A database (in .txt) was created for information processing. The results were presented in tables and graphs. A computer program was implemented in GNU Octave 4.0 software (free software, License 2015-05-29, Universidad de Oriente, Santiago de Cuba, Cuba) to show figures. As part of the GNU Project, GNU Octave is free software under the terms of the GNU General Public License. The website was http://gnu.org/software/octave.
Free Software Foundation funds the GNU Project. Developer(s): John W. Eaton and many collaborators. This software was executed in a 256-core processor HPC with 256 GB RAM.

Pearson and Spearman's rho correlation coefficients were implemented in the statistical program Minitab 14 (Minitab Inc. for Windows, 2003, free software, National Institute of Standards and Technology, Pennsylvania State University, USA, https://www.minitab.com/en-mx/ products/minitabs). This program ran on a computer (Departamento de Matemática, Universidad de Oriente) with operating system Windows 8 con RAM 2.6 GB; 64 bits, processor 64 , Inter $\mathrm{R}$ cor etm). The duration of the statistical processing of data was approximately $2 \mathrm{~s}$.

Data will be kept for 15 years in the Oncology and Hematology department of the hospital Infantil Sur Antonio María Béguez César.

\section{Results}

Pearson and Spearman's rho correlation coefficients gave similar results when two bioelectrical parameters of cancer patients were compared. For solid tumors, correlation coefficients $\left(p\right.$-value) between $(\mathrm{R} / \mathrm{H})_{\mathrm{p}}$ and $(\mathrm{Xc} / \mathrm{H})_{\mathrm{p}}$, $\theta_{\mathrm{p}}$ and $(\mathrm{R} / \mathrm{H})_{\mathrm{p}}$, and $\theta_{\mathrm{p}}$ and $(\mathrm{Xc} / \mathrm{H})_{\mathrm{p}}$ were $0.49(p=0.001)$, $-0.123(p=0.433)$ and $0.313(p=0.041)$, respectively. The samples used for these correlations are shown in Table 2. For non-solid tumors, correlation coefficients (p-value) between $(\mathrm{R} / \mathrm{H})_{\mathrm{p}}$ and $(\mathrm{Xc} / \mathrm{H})_{\mathrm{p}}, \theta_{\mathrm{p}}$ and $(\mathrm{R} / \mathrm{H})_{\mathrm{p}}$, and $\theta_{\mathrm{p}}$ and $(\mathrm{Xc} / \mathrm{H})_{\mathrm{p}}$ were $0.42(p=0.002),-0.134(p=$ $0.513)$ and $0.298(p=0.036)$, respectively. The samples used for these correlations are shown in Table 3. For both tumor types, similar correlation coefficients were reported when the analysis included $R_{p}$ and $X_{c}, \theta_{p}$ and $\mathrm{R}_{\mathrm{p}}$ and $\theta_{\mathrm{p}}$ and $\mathrm{Xc}_{\mathrm{p}}$.

The code, cancer histological variety, age, gender, height and values of $R_{p},(R / H)_{p}, X c_{p},(X c / H)_{p}, \theta_{p}$ and $d_{p r}$ for each patient with $\mathrm{Ts}$ and $\mathrm{Tns}$ were showed in $\mathrm{Ta}$ bles 2 and 3 , respectively. $R_{p},(R / H)_{p}, X_{p},(X c / H)_{p}$ and $\theta_{\mathrm{p}}$ were used to refer the values of $\mathrm{R}, \mathrm{R} / \mathrm{H}, \mathrm{Xc}, \mathrm{Xc} / \mathrm{H}$ and $\theta$ for these patients. $58.14 \%(25 / 43)$ corresponded to patients with Ts and $41.86 \%(18 / 43)$ related to patients with Tns were revealed in these two tables. In addition, Table 2 revealed that $76.00 \%(19 / 25)$ of Ts were distributed among non-Hodgkin lymphoma $(12 / 25=48.00 \%)$ and central nervous system $(7 / 25=28.00 \%)$ tumors. $88.89 \%(16 / 18)$ of Tns corresponded to acute lymphoid leukemia (Table 3). Of the total number of patients, $37.21 \%(16 / 43), 27.91 \%(12 / 43)$ and $16.28 \%$ (7/43) corresponded to patients with acute lymphoid leukemia, nonHodgkin lymphoma and nervous system central tumors, respectively. Of the 25 patients with Ts, $76.00 \%(19 / 25)$ related to the male gender and $24.00 \%$ to females. Of the 18 patients with Tns, $61.11 \%(11 / 18)$ corresponded to the male gender and $38.89 \%(7 / 18)$ to the female gender. 
Table 2 Different variables for each patient with solid tumor

\begin{tabular}{|c|c|c|c|c|c|c|c|c|c|c|c|}
\hline $\bar{C}$ & Histological variety & $\begin{array}{l}\text { Age } \\
\text { (years) }\end{array}$ & Gender & $\begin{array}{l}\text { W } \\
(\mathrm{kg})\end{array}$ & $\begin{array}{l}\mathrm{H} \\
(\mathrm{m})\end{array}$ & $\begin{array}{l}R_{p} \\
(\Omega)\end{array}$ & $\begin{array}{l}(\mathrm{R} / \mathrm{H})_{\mathrm{p}} \\
(\Omega / \mathrm{m})\end{array}$ & $\begin{array}{l}X C_{p} \\
(\Omega)\end{array}$ & $\begin{array}{l}(\mathrm{Xc} / \mathrm{H})_{\mathrm{p}} \\
(\Omega / \mathrm{m})\end{array}$ & $\begin{array}{l}\theta_{p} \\
\left({ }^{\circ}\right)\end{array}$ & $\begin{array}{l}d_{p r} \\
(\Omega / m)\end{array}$ \\
\hline 1 & Nephroblastoma $^{1}$ & 2 & $\mathrm{~F}$ & 12 & 0.87 & 650 & 747.13 & 41.0 & 47.13 & 3.6 & 24.95 \\
\hline 2 & Testicle & 2 & M & 11 & 0.88 & 705 & 801.14 & 51.2 & 58.18 & 4.2 & 61.08 \\
\hline 3 & Histiocytiosis $^{*}$ & 2 & M & 13 & 0.96 & 804 & 837.50 & 60.2 & 62.71 & 4.3 & 96.45 \\
\hline 5 & CNS & 3 & $\mathrm{~F}$ & 17 & 1.03 & 833 & 808.74 & 76.7 & 74.47 & 5.3 & 67.43 \\
\hline 6 & $\mathrm{NHL}$ & 3 & M & 11 & 0.88 & 837 & 951.14 & 56.2 & 63.86 & 3.8 & 209.85 \\
\hline 11 & $\mathrm{NHL}$ & 4 & M & 21 & 1.07 & 726 & 678.50 & 57.8 & 54.02 & 4.6 & 28.81 \\
\hline 12 & $\mathrm{NHL}$ & 4 & M & 20 & 1.02 & 872 & 854.90 & 57.3 & 56.18 & 3.8 & 203.82 \\
\hline 13 & Fibrosarcoma ${ }^{2}$ & 5 & M & 25 & 1.25 & 612 & 489.60 & 53.6 & 42.88 & 5.0 & 162.87 \\
\hline 14 & $\mathrm{NHL}$ & 5 & M & 22 & 1.05 & 901 & 858.10 & 51.4 & 48.95 & 3.3 & 207.39 \\
\hline 15 & CNS & 5 & $\mathrm{~F}$ & 19 & 1.10 & 724 & 658.18 & 59.8 & 54.36 & 4.7 & 11.26 \\
\hline 16 & $\mathrm{NHL}$ & 5 & M & 15 & 1.35 & 847 & 627.41 & 60.4 & 44.74 & 4.1 & 30.11 \\
\hline 17 & $\mathrm{NHL}$ & 6 & $\mathrm{~F}$ & 22 & 0.70 & 735 & 1050.00 & 36.3 & 51.86 & 2.8 & 471.53 \\
\hline 19 & CNS & 7 & M & 24 & 1.20 & 740 & 616.67 & 60.8 & 50.67 & 4.7 & 38.77 \\
\hline 20 & CNS & 7 & $\mathrm{~F}$ & 19.5 & 1.19 & 1057 & 888.24 & 70.1 & 58.91 & 3.8 & 309.74 \\
\hline 21 & $\mathrm{NHL}$ & 8 & M & 26 & 1.22 & 873 & 715.57 & 77.4 & 63.44 & 5.1 & 202.96 \\
\hline 22 & Histiocytiosis $^{*}$ & 8 & M & 24 & 1.45 & 732 & 504.83 & 61.1 & 42.14 & 4.8 & 12.06 \\
\hline 23 & $\mathrm{NHL}$ & 10 & M & 25 & 1.26 & 777 & 616.67 & 56.6 & 44.92 & 4.2 & 155.38 \\
\hline 25 & Osteosarcoma & 11 & $\mathrm{~F}$ & 29 & 1.38 & 1017 & 736.96 & 71.0 & 51.45 & 4.0 & 275.19 \\
\hline 26 & $\mathrm{NHL}$ & 11 & $M$ & 49 & 1.39 & 611 & 439.57 & 60.3 & 43.38 & 5.6 & 22.03 \\
\hline 27 & $\mathrm{NHL}$ & 11 & $M$ & 40 & 1.50 & 609 & 406.00 & 60.4 & 40.27 & 5.7 & 55.71 \\
\hline 30 & CNS & 12 & $M$ & 35 & 1.40 & 642 & 458.57 & 58.3 & 41.64 & 5.2 & 39.02 \\
\hline 32 & $\mathrm{NHL}$ & 12 & $M$ & 49 & 1.45 & 754 & 520.00 & 65.9 & 45.45 & 5.0 & 100.42 \\
\hline 37 & $\mathrm{NHL}$ & 15 & $M$ & 63 & 1.86 & 511 & 274.73 & 41.6 & 22.37 & 4.7 & 62.21 \\
\hline 40 & CNS & 15 & M & 48 & 1.60 & 673 & 420.63 & 49.5 & 30.94 & 4.2 & 85.64 \\
\hline 43 & CNS & 17 & $M$ & 60 & 1.73 & 580 & 335.26 & 57.7 & 33.35 & 5.7 & 42.96 \\
\hline
\end{tabular}

${ }^{1}$ Right kidney. ${ }^{2}$ Right gluteus. *Benign process with malignant behavior. Code (C), male gender (M), female gender (F), weight (W) and height (H) for each patient were specified. CNS symbolized Central Nervous System. NHL denoted Non-Hodgkin Lymphoma. $R_{p},(R / H)_{p}, X_{p},(X c / H)_{p}$ and $\theta_{p}$ were the body electrical resistance, $R_{p}$ per unit of height, the body capacitive electrical reactance, $X c_{p}$ per unit of height and the body phase angle of each patient, respectively. $d_{p r}$ represented the distance between the points $\left((R / H)_{r},(X c / H)_{r}\right)$ and $\left((R / H)_{p},(X c / H)_{p}\right)$, for each gender and age group. The subscript $p$ was referred to the solid tumor child while the subscript $r$ to the population of apparently healthy children. Values of $(\mathrm{R} / \mathrm{H})_{\mathrm{r}}$ and $(\mathrm{Xc} / \mathrm{H})_{\mathrm{r}}$ were shown in Table 1 and reported in [16] (courtesy of MSc. Alcibiade Lara Lafargue and Centro Nacional de Electromagnetismo Aplicado)

Of the total number of patients, $69.77 \%(30 / 43)$ and $30.23 \%$ (13/43) belonged to the male and female genders, respectively.

The highest $d_{p r}$ value of all patients with Tns and Ts was observed for Code 10 (Table 2) and Code 17 (Table 3), respectively. Of the total number of patients, $39.53 \%$ (17/43), $25.58 \%$ (11/43), $6.98 \%$ (3/43), 4.65\% (2/43), 13.95\% (6/43), $2.32 \%(1 / 43), 4.65 \%(2 / 43)$ and $2.32 \%(1 / 43)$ were distributed on the scale of $d_{\mathrm{pr}} 1-50,51-100,101-150,151-200$, $201-250,251-300,301-350$ and $>350 \Omega / \mathrm{m}$, respectively. $33.33 \%$ (9/27), 22.22\% (6/27), 7.41\% (2/27), 7.41\% (2/27), $18.53 \%$ (5/27), 3.70\% (1/27), 3.70\% (1/27) and 3.70\% (1/27) of the patients with Ts were distributed in the $d_{p r} 1-50$ scales 51-100, 101-150, 151-200, 201-250, 251-300, 301350 and $>350 \Omega / m$, respectively. For these respective $d_{p r}$ scales, distribution percentages of patients with Tns were
$50.00 \%$ (8/16), 31.25\% (5/16), 6.25\% (1/16), $0.00 \%(0 / 16)$, $6.25 \%(1 / 16), 0.00 \%(0 / 16)$ and $6.25 \%(1 / 16)$.

For each gender and age group shown in Table 1, all possible combinations of $(\mathrm{R} / \mathrm{H})_{\mathrm{r}}$ and $(\mathrm{Xc} / \mathrm{H})_{\mathrm{r}}$ for a population of apparently healthy pediatric subject were included in delimited rectangles with continuous and dashed lines for the male and female genders, respectively (Fig. 1). This meant that body bioelectric-physiological states of these subjects were only possible if they belonged to the interior and contour of their respective rectangles. In other words, these states were not possible outside of them. $\mathrm{R} / \mathrm{H}$ and $\mathrm{Xc} / \mathrm{H}$ values outside the rectangle represented a subject with some type of pathology (for example, cancer patients), for each gender and age group. Therefore, in this study, this rectangle for apparently healthy subjects was named the reference rectangle for body bioelectric states 
Table 3 Different variables for each patient with non-solid tumor

\begin{tabular}{|c|c|c|c|c|c|c|c|c|c|c|c|}
\hline $\bar{C}$ & Type of tumor & $\begin{array}{l}\text { Age } \\
\text { (years) }\end{array}$ & Gender & $\begin{array}{l}\text { W } \\
(\mathrm{kg})\end{array}$ & $\begin{array}{l}\mathrm{H} \\
(\mathrm{m})\end{array}$ & $\begin{array}{l}R_{p} \\
(\Omega)\end{array}$ & $\begin{array}{l}(\mathrm{R} / \mathrm{H})_{\mathrm{p}} \\
(\Omega / \mathrm{m})\end{array}$ & $\begin{array}{l}X c_{p} \\
(\Omega)\end{array}$ & $\begin{array}{l}(\mathrm{Xc} / \mathrm{H})_{\mathrm{p}} \\
(\Omega / \mathrm{m})\end{array}$ & $\begin{array}{l}\theta_{p} \\
\left({ }^{\circ}\right)\end{array}$ & $d_{p r}(\Omega / m)$ \\
\hline 4 & CML & 3 & M & 15 & 1.09 & 751 & 688.99 & 39.2 & 35.96 & 3.0 & 62.99 \\
\hline 7 & ALL & 3 & M & 12 & 0.95 & 824 & 867.37 & 37.7 & 39.68 & 2.6 & 129.78 \\
\hline 8 & ALL & 3 & $\mathrm{~F}$ & 16 & 0.95 & 674 & 709.47 & 80.3 & 84.53 & 4.3 & 34.71 \\
\hline 9 & ALL & 3 & M & 12 & 0.95 & 825 & 868.42 & 37.7 & 39.68 & 2.6 & 130.80 \\
\hline 10 & ALL & 3 & M & 20 & 1.45 & 607 & 418.62 & 39.1 & 26.97 & 3.7 & 325.76 \\
\hline 18 & ALL & 6 & M & 29 & 1.10 & 623 & 566.36 & 48.9 & 44.45 & 4.5 & 17.82 \\
\hline 24 & ALL & 10 & M & 33 & 1.50 & 752 & 501.33 & 67.4 & 44.93 & 5.1 & 40.09 \\
\hline 28 & ALL & 11 & M & 35 & 1.48 & 701 & 473.65 & 46.5 & 31.42 & 3.8 & 18.88 \\
\hline 29 & AML & 12 & $\mathrm{~F}$ & 35 & 1.52 & 786 & 517.11 & 51.0 & 33.55 & 3.7 & 98.02 \\
\hline 31 & ALL & 12 & M & 28 & 1.40 & 889 & 635.00 & 63.1 & 45.01 & 4.4 & 215.41 \\
\hline 33 & ALL & 12 & M & 29 & 1.76 & 659 & 374.43 & 50.7 & 28.81 & 4.4 & 47.53 \\
\hline 34 & ALL & 13 & $F$ & 54 & 1.57 & 755 & 480.89 & 69.9 & 44.46 & 5.3 & 67.90 \\
\hline 35 & ALL & 13 & $\mathrm{~F}$ & 57 & 1.64 & 714 & 435.37 & 58.0 & 35.37 & 4.6 & 23.83 \\
\hline 36 & ALL & 14 & $F$ & 47 & 1.63 & 833 & 541.72 & 76.7 & 47.06 & 5.3 & 98.10 \\
\hline 38 & ALL & 15 & $\mathrm{~F}$ & 92 & 1.70 & 606 & 356.47 & 55.0 & 32.35 & 5.2 & 57.64 \\
\hline 39 & ALL & 15 & $\mathrm{~F}$ & 44 & 1.55 & 683 & 440.65 & 59.9 & 38.65 & 5.0 & 28.09 \\
\hline 41 & ALL & 15 & M & 82 & 1.87 & 508 & 271.66 & 45.2 & 24.17 & 5.1 & 64.82 \\
\hline 42 & ALL & 16 & M & 80 & 1.71 & 512 & 299.42 & 53.5 & 31.29 & 6.0 & 36.24 \\
\hline
\end{tabular}

Code $(C)$, male gender $(M)$, female gender $(F)$, weight $(W)$ and height $(H)$ for each non-solid tumor patient were specified. $C M L$ represented the chronic myeloid leukemia. ALL denoted the acute lymphoid leukemia and $A M L$ the acute myeloid leukemia. $R_{p},(R / H)_{p}, X c_{p},(X c / H)_{p}$ and $\theta_{p}$ were the body electrical resistance, $R_{p}$ per unit of height, the body capacitive electrical reactance, $X c_{p}$ per unit of height and the body phase angle of each patient, respectively. $d_{p r}$ symbolized the distance between the points $\left((R / H)_{r},(X c / H)_{r}\right)$ and $\left((R / H)_{p},(X c / H)_{p}\right)$, for each gender and age group. The subscript $p$ was referred to the non-solid tumor child while the subscript $r$ to the population of apparently healthy children. Values of $(R / H) r$ and $(\mathrm{Xc} / \mathrm{H})_{\mathrm{r}}$ were shown in Table 1 and reported in [16] (courtesy of MSc.

Alcibiade Lara Lafargue and Centro Nacional de Electromagnetismo Aplicado)

$\left(\mathrm{R}_{\mathrm{r}}\right)$. The normal intervals for each rectangle displayed in Fig. 1 were made using \pm 2 standard deviations of reference source data [16], as displayed in Table 1.

In Fig. 1, the center circle in $R_{r}$ delimited with a continuous line named $\left(\mathrm{R}_{\mathrm{rc}}\right)$ represented the ordered pair $\left((\mathrm{R} / \mathrm{H})_{\mathrm{r}},(\mathrm{Xc} / \mathrm{H})_{\mathrm{r}}\right)$ for the male gender. The unfilled triangle in the center of the $\mathrm{R}_{\mathrm{r}}$ delimited with dashed line, named $R_{r d}$, symbolized the ordered pair $\left((R / H)_{r}\right.$, $(X c /$ $H)_{r}$ ) for the female gender. In addition, $R_{r c}, R_{r d}$ and the body bioelectric state of each male and female patient with Ts and Tns were displayed in this figure for 2-3 years (Fig. 1a), 4-5 years (Fig. 1b), 6-7 years (Fig. 1c), 89 years (Fig. 1d), 10-11 years (Fig. 1e), 12 years (Fig. 1f), 13-16 years (Fig. 1g) and 17-59 years (Fig. 1h). Additionally, Fig. 1 showed that $93.02 \%$ (40/43) of pediatric patients with cancer were outside their respective $R_{r}$. Three patients (Codes 24, 26 and 30) were only in their corresponding $\mathrm{R}_{\mathrm{r}}$, according to the age group. Of these 40 patients, $72.5 \%(29 / 40)$ had $(\mathrm{Xc} / \mathrm{H})_{\mathrm{p}}<(\mathrm{Xc} / \mathrm{H})_{\mathrm{r}}$ while values of $(\mathrm{R} / \mathrm{H})_{\mathrm{p}}$ were distributed along the $\mathrm{R} / \mathrm{H}$ axis. $90.70 \%(39 / 43)$ of all patients had a $\theta_{\mathrm{p}}<\theta_{\mathrm{r}}$, except those labeled with Codes 5, 26, 27 and 42. This condition for $\theta_{\mathrm{p}}$ was observed in $88.00 \%(22 / 25)$ and $94.44 \%(17 / 18)$ of patients with Ts and Tns, respectively.
In Fig. 2, $R_{\mathrm{rc}}$ and $R_{\mathrm{rd}}$ of all apparently healthy pediatric subjects were shown. The set of these $R_{r c}$ and $R_{r d}$ defined the entire region in which were most likely present all bioelectric states of them. In addition, the body bioelectric state of each male and female cancer patient was illustrated in this figure in order to know if the body bioelectric state of the pediatric patient depended on gender, age group and tumor histological variety.

Figure 2 revealed that $55.81 \%(24 / 43)$ of body bioelectric states of cancer patients were distributed in $R_{r c}$ or their respective neighborhoods, by gender, age group and experimental group. The body bioelectric states of the remaining patients $44.19 \%$ (19/43) were distributed regardless of gender and age group. These findings were observed in $60.00 \%(15 / 25)$ and $50.00 \%$ (9/18) of patients with Ts and Tns, respectively. Unlike Fig. 1, the overlapping of the body bioelectric states of patients with Tns (Codes 7 and 9, 24 and 34) and Ts (Codes 26 and 30, 13 and 22, 11 and 15) was showed in Fig. 2. Furthermore, there was an overlap of the body bioelectric states in some patients with cancer (Codes 37 and 41; 38 and 43; 13 and 34; 24 and 32; 5, 22 and 36). 

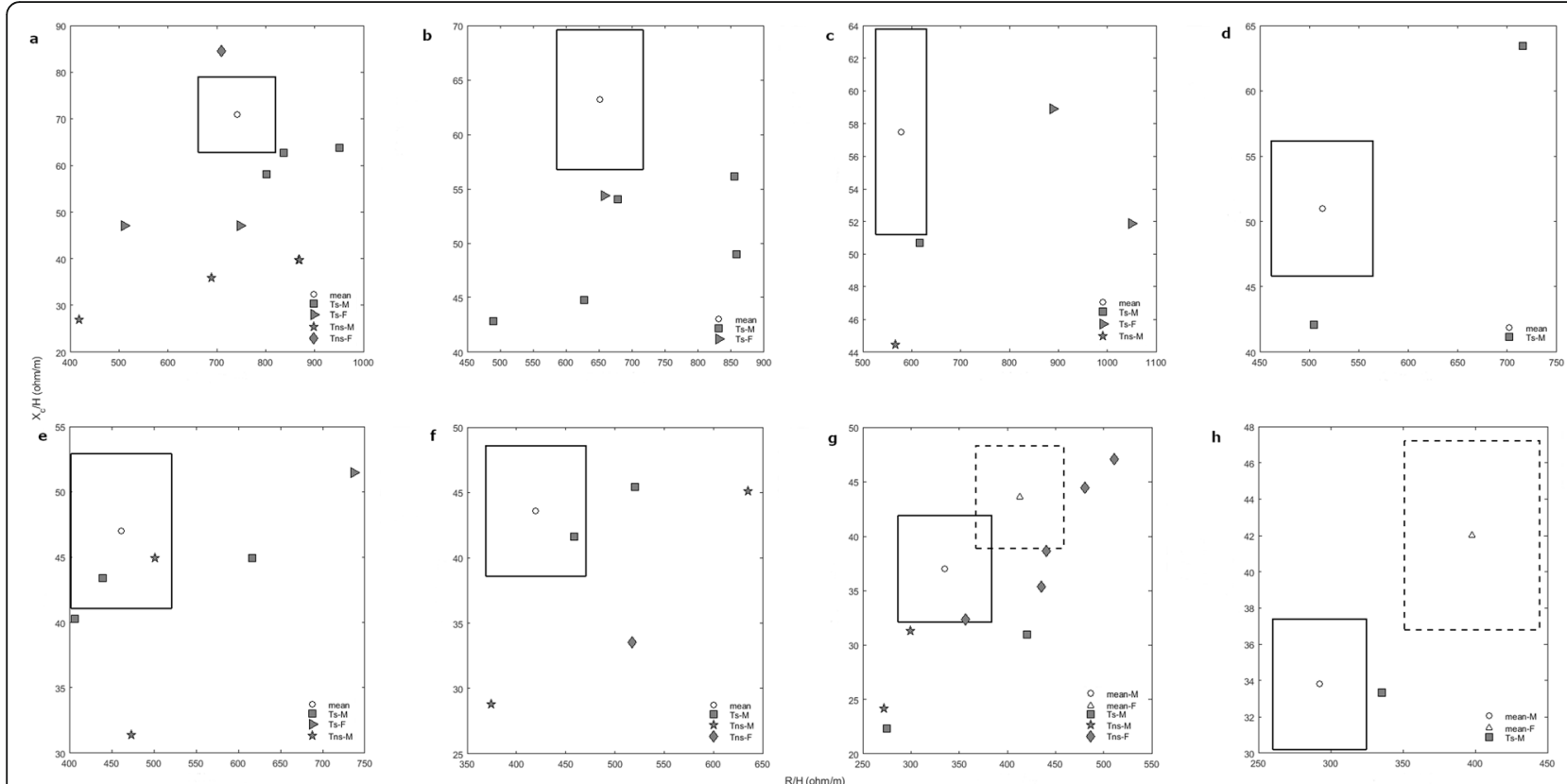

Fig. $1 \mathrm{XC} / \mathrm{H}$ versus R/H plot for apparently healthy and cancer children for (a) 2-3 years, (b) 4-5 years, (c) 6-7 years, (d) 8-9 years, (e) 10-11 years, (f) 12 years, (g) 13-16 years and (h) 17-59years. The height of the patient was represented by $\mathrm{H}$. Each reference rectangle was done by mean \pm 2 standard deviation reported in [16] (displayed in Table 1, courtesy of MSc. Alcibiade Lara Lafargue and Centro Nacional de Electromagnetismo Aplicado) and delimited with continuous line (for male) and discontinuous line (for female). Average values for male and female were represented by the circle and the unfilled triangle, respectively. The body bioelectric state of each cancer child was displayed: male child with solid tumor (Ts-M or filled square), non-solid male child (Tns-M or filled star), female child with solid tumor (Ts-F or filled triangle) and non-solid female child (Tns-F or filled rhombus)

\section{Discussion}

The results of this study are valid for the research period and the number of patients who fulfill the inclusion criteria. These inclusion criteria and low prevalence of cancer children in the province of Santiago de Cuba may explain why the sample size of this study is lower. In addition, the race of cancer children in this study is the same than the one reported in [16] because the ethnography of Santiago de Cuba population is characterized by a mixture of several race ethnicities (European whites, aboriginal Indians and African blacks). Nevertheless, the gender ratio of cancer children is different to that reported in [16]. This difference may be explained because gender ratio can be controlled/fixed in a population study, but not in a study with cancer patients. Gender ratio of cancer patients depends on disease prevalence for gender and age group, and inclusion, exclusion and interruption criteria.

On the other hand, results of this study confirm that acute lymphoid leukemia, non-Hodgkin lymphoma and cancer of the central nervous system are most frequently observed in untreated pediatric patients, as in [2-4, 3841]. Additionally, this study confirms that acute lymphoid leukemia is more frequent than acute myeloid leukemia, in agreement with $[39,41]$. The predominance of the male gender of these patients confirms the result documented in [42] and contradicts that reported by Toquica et al. [41].

For both tumor types, $p$-values indicated that correlation between $\theta_{\mathrm{p}}$ and $(\mathrm{R} / \mathrm{H})_{\mathrm{p}}$ was non-significant and therefore non-lineal. Nevertheless, significant, lineal and low correlations were reported for $\left((\mathrm{R} / \mathrm{H})_{\mathrm{p}}\right.$ and $\left.(\mathrm{Xc} / \mathrm{H})_{\mathrm{p}}\right)$ and $\left(\theta_{\mathrm{p}}\right.$ and $\left.(\mathrm{Xc} / \mathrm{H})_{\mathrm{p}}\right)$.

Several reasons can be attributed to nearly $10 \%$ of cancer patient not satisfying the criteria of phase angle, such as: the biological individuality, the phase angle does not have to change once the cancer patients is diagnosed for the first time, not all new diagnosed cancer children have the same performance status and detected at the same time and not all tumor type influences equally $\theta_{\mathrm{p}}$. These reasons justify why the individual analysis of the bioelectrical parameters is suggested in this study.

The finding that $90.70 \%$ of all cancer patients satisfy $\theta_{\mathrm{p}}<\theta_{\mathrm{r}}$ confirms that the phase angle may be used as an indicator of disease severity and quality of life and loss of body homeostasis of the cancer patient, a matter that agrees with [14]. These findings have been confirmed in adult patients with cancer $[8,42,43]$ and in patients with other pathologies $[8,13,15,34,44]$. Gupta et al. [42] report an average survival less than 3 months in patients with lung cancer whose $\theta_{\mathrm{p}}$ values are between 2 and $3^{\circ}$. This finding is confirmed in other studies $[8,13$, 


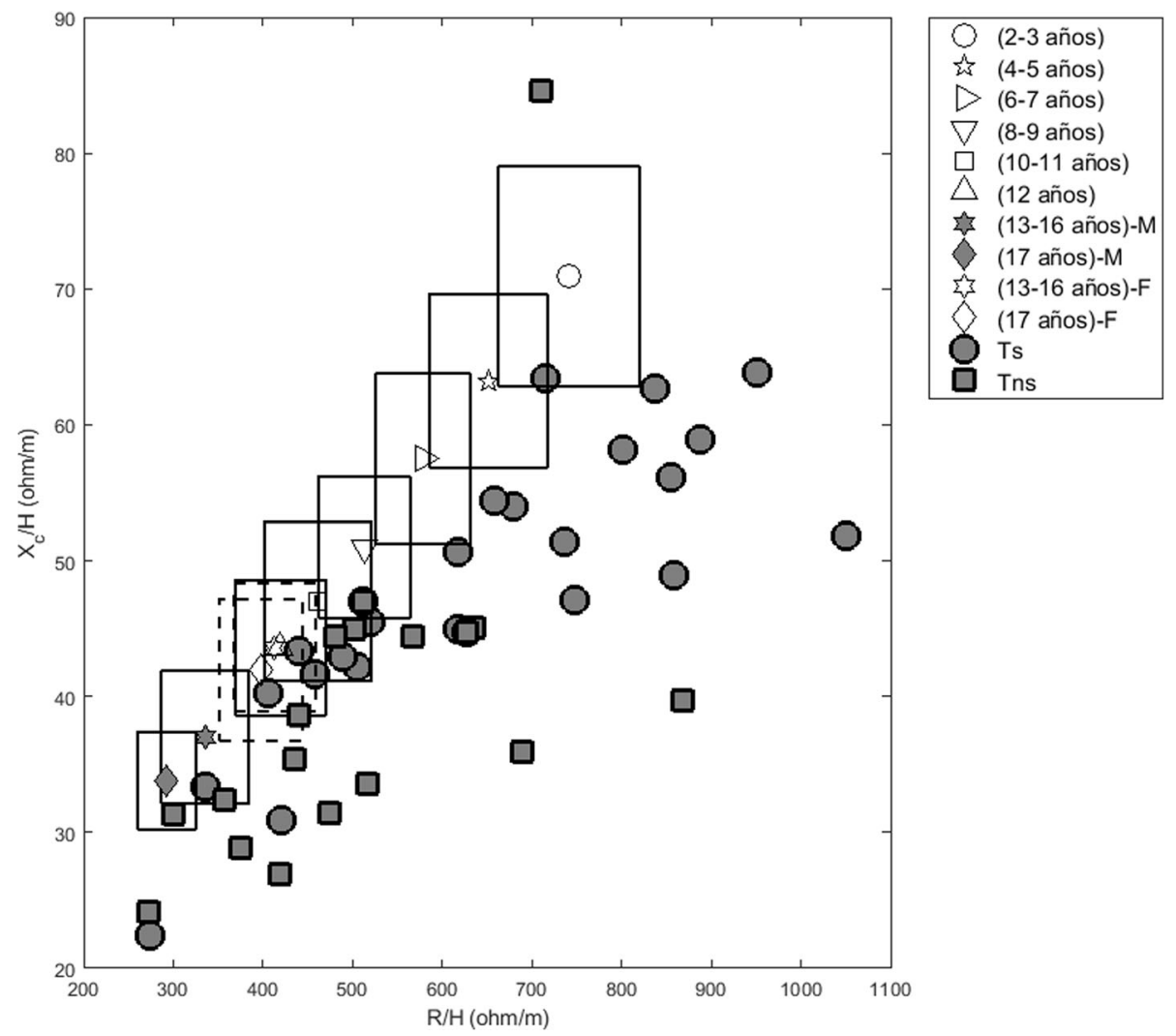

Fig. 2 Set of reference rectangles from 2 to 80 years of age (means \pm 2 standard deviations [16] were displayed in Table 1 (courtesy of MSc. Alcibiade Lara Lafargue and Centro Nacional de Electromagnetismo Aplicado) and body bioelectric state of each child, for all age groups and gender: male with solid tumor (Ts-M or filled circle), non-solid tumor male child (Tns-M or filled square), female with solid tumor (Ts-F or filled triangle) and non-solid tumor female child (Tns-F or filled star)

$15,34,42-44]$. Nevertheless, the effect of $\theta_{\mathrm{p}}$ on the survival is not discussed in this work because no patient dies.

In this study, $\theta_{\mathrm{p}}<\theta_{\mathrm{r}}$ may be explained because in the majority of cancer patients prevails that $(\mathrm{Xc} / \mathrm{H})_{\mathrm{p}}<(\mathrm{Xc} / \mathrm{H})_{\mathrm{r}}$ for all value of $(\mathrm{R} / \mathrm{H})_{\mathrm{p}}$, for each age group, gender and experimental group. This may suggest that component $(\mathrm{Xc} / \mathrm{H})_{\mathrm{p}}$ of the ordered pair $\left((\mathrm{R} / \mathrm{H})_{\mathrm{p}},(\mathrm{Xc} / \mathrm{H})_{\mathrm{p}}\right)$ prevails in the body bioelectric state of the cancer patient. From the biophysical point of view, $(\mathrm{Xc} / \mathrm{H})_{\mathrm{p}}$ cannot decrease until zero because $\theta_{\mathrm{p}}$ tends toward zero, which means the death of the cancer patients. This occur for all values of $(\mathrm{R} / \mathrm{H})_{\mathrm{p}}$, confirming that $(\mathrm{R} / \mathrm{H})_{\mathrm{p}}$ and $\theta_{\mathrm{p}}$ are not linearly correlated. This may suggest that $(\mathrm{Xc} / \mathrm{H})_{\mathrm{p}}$ decreases until its minimum value that brings about a quicker decrease of $(\mathrm{R} / \mathrm{H})_{\mathrm{p}}$ than $(\mathrm{Xc} / \mathrm{H})_{\mathrm{p}}$ so that $\theta_{\mathrm{p}}$ stays in its normal range. From the thermodynamic point of view, a quick decrease of $(\mathrm{R} / \mathrm{H})_{\mathrm{p}}$ may mean the occurrence of different self-organized biophysical-chemical processes in the organism that reduce the body bioenergetics losses to guarantee its maximum survival and selfpreservation as a living system. One of the main characteristics of the biological organisms, as open systems, is to tend toward its maximum survival.
If net inductive effects of the patient [45] are neglected, $\mathrm{Xc}_{\mathrm{p}}$ may be due to the different total capacitive electrical reactance contributions of the tumor (named $\left.\mathrm{Xc}_{\mathrm{t}}\right)$, healthy tissue $\left(\mathrm{Xc}_{\mathrm{o}}\right)$ and tumorsurrounding healthy tissue interface (named $\mathrm{Xc}_{\mathrm{o}_{-t}}$ ). This interface is the tumor micro-environment and constitutes by the mixture of cancer cells, normal cells and other components. $\mathrm{Xc}_{\mathrm{p}}$ may be expressed in a first approximation as $X c_{p} \cong X c_{t}+X c_{o}+X c_{o-t}$. As the capacitive contribution predominates in each tissue, $X c=1 /(2 \pi f C)$, where $C$ is the electrical capacity of the biological tissue under consideration and $\mathrm{f}$ is the working frequency (50 $\mathrm{kHz}$ ). For this reason, $\mathrm{Xc}_{\mathrm{p}}, \mathrm{Xc}_{\mathrm{t}}, \mathrm{Xc}_{\mathrm{o}}$ and $\mathrm{Xc}_{\mathrm{o}-\mathrm{t}}$ may be substituted for their respective electrical capacities. Therefore, $C_{\mathrm{p}}$ may be calculated approximately as $C_{p} \cong$ $C_{t} C_{o} C_{o-t} /\left(C_{o} C_{o-t}+C_{t} C_{o-t}+C_{t} C_{o}\right)$, where $C_{\mathrm{p}}, C_{\mathrm{t}}, \mathrm{C}_{\mathrm{o}}$ and $\mathrm{C}_{\mathrm{o}-\mathrm{t}}$ are the total electrical capacities of the entire patient, the tumor, the healthy tissue and the surrounding healthy tissue-tumor interface, respectively.

It has been experimentally documented that $C_{o}>>C_{t}$ (e.g., $C_{t}=3.546 \pm 1.931 \mathrm{pF}$ for lung cancer and $C_{o}=$ $893 \pm 572 \mathrm{pF}$ for normal lung tissue) and the increase in capacitance of normal cells when cancer cells are added 
to them [46]. The first finding is confirmed by other authors $[47-50]$. The second finding may mimic the mixture of cancer and normal cells in the tumor surrounding healthy tissue interface. These two findings may suggest that $C_{o} C_{o-t}>>C_{t} C_{o}>C_{t} C_{o-t}$ and therefore $C_{p} \cong C_{t}$.

In addition, $C_{p} \cong C_{t}$ may also be obtained if contributions of $\mathrm{Xc}_{\mathrm{o}-\mathrm{t}}$ to $\mathrm{Xc}_{\mathrm{p}}\left(\mathrm{C}_{\mathrm{o}-\mathrm{t}}\right.$ to $\left.\mathrm{C}_{\mathrm{p}}\right)$ are neglected with respect to those of $\mathrm{Xc}_{\mathrm{t}}$ and $\mathrm{Xc}_{\mathrm{o}}\left(\mathrm{C}_{\mathrm{t}}\right.$ and $\left.\mathrm{C}_{\mathrm{o}}\right)$. In this case, $(X c)_{p} \cong(X c)_{t}+(X c)_{o}$ and $C_{p} \cong C_{t} C_{o} /\left(C_{t}+C_{o}\right) . C_{p} \cong C_{t}$ is due to the fact as normal cells have dielectric constants and membrane electrical capacities greater than those of cancer cells [46-50]. In contrast, Frike and Morse [51] report that $C_{t}>C_{0}$. The fundamental contributions of $\mathrm{Xc}_{\mathrm{t}}$ and $\mathrm{Xc}_{\mathrm{o}}$ to $\mathrm{Xc}_{\mathrm{p}}$ may be argued because electrical activities occur mainly in the tumor and in healthy tissue (distant from the tumor). This result is expected because normal and cancerous cells are mainly confined in these two tissues and not in the tumor-surrounding healthy tissue interface. This aspect may explain in part why there are differences in the electrical properties of the tumor and healthy tissue, in agreement with others studies $[47,48,52,53]$.

The finding $C_{p} \cong C_{t}$ confirms that electrical properties and biological characteristics of the cancer histological variety significantly influence the body homeostasis, quality of life, survival and body bioelectrical and physiological parameters of a patient with Ts/Tns. Nevertheless, the tumor-surrounding healthy tissue interface cannot be completely neglected because it influences the electrical-chemical microenvironment of the tumor, which is related to the aggressiveness and metastasis of it [54-56] and its protection against the attack of cellular and humoral elements of the immune system [57, 58].

Due to the close relationship between the electrical and physiological parameters of a biological tissue $[8,21$, $22,34,44,58,59]$, changes of $C_{t}$ and $X c_{t}$ may be related to those of the transmembrane potential and the membrane permeability of cancer cells [47]. In turn, these changes have been related to other alterations observed in cancer cells as high mitotic activity, increase in the electronegativity of the extracellular surface, changes in intracellular and extracellular ionic concentrations, breakdown of homeostasis of electronic transport in the cell membrane, the depletion of adenosine triphosphate, the failure of the contact inhibition mechanism, morphological changes, aggressiveness, metastatic capacity, among others $[47,56,59]$. This leads to an alteration of the body homeostasis in cancer patients.

Loss of body homeostasis of a patient (child or adult) with cancer may lead to the decrease of the body cell mass and changes of its cell metabolism, body composition and distribution of total body water, as reported in $[33,60,61]$. This may explain the cachexia and modifications in $(\mathrm{R} / \mathrm{H})_{\mathrm{p}},(\mathrm{Xc} / \mathrm{H})_{\mathrm{p}}$ and $\theta_{\mathrm{p}}$ observed in cancer patients, explaining in part why $(\mathrm{Xc} / \mathrm{H})_{\mathrm{p}}<(\mathrm{Xc} / \mathrm{H})_{\mathrm{r}}$ for all $(\mathrm{R} / \mathrm{H})_{p}$ value observed in the majority of patients with Ts/ Tns. This finding may suggest that losses of the body energy reserves of the patient with Ts/Tns (related to (Xc/ $\mathrm{H})_{\mathrm{p}}$ ) are faster than the body heat loss (related to $(\mathrm{R} / \mathrm{H})_{\mathrm{p}}$ ). This corroborates that $\theta_{\mathrm{p}}<\theta_{\mathrm{r}}$, as in [15, 43], and the body metabolism and body composition alterations of these cancer patients, as in [34, 60, 61]. It is important to note that heat loss is noticeable as $R_{p}$ increases.

The finding $(\mathrm{R} / \mathrm{H})_{\mathrm{p}}>(\mathrm{R} / \mathrm{H})_{\mathrm{r}}$ observed in some patients with $\mathrm{Ts} / \mathrm{Tns}$ may be explained because body heat loss and water and ions body imbalances in cancer patient are noticeable compared to those in apparently healthy subjects. In turn, these alterations may be related to the biophysical-chemical-bioelectrical-energetic changes in the cell membrane, as discussed above.

Despite the increase of $(\mathrm{R} / \mathrm{H})_{\mathrm{p}}$ in these cancer patients, $\theta_{\mathrm{p}}$ decreases slightly with respect to $\theta_{\mathrm{r}}$, for each gender and age group. This may suggest that these patients still have sufficient energy reserves to compensate the possible heat loss. If these losses prevail, $\theta_{\mathrm{p}}$ would decrease and therefore a low quality of life and short survival of the patient with Ts/Tns, in agreement with [42]. This statement would be noticeable when $\mathrm{Xc}_{\mathrm{p}}$ also decreases, in accordance with [37].

In general, $|\mathrm{Z}|$ and $\theta$ fix the position of any bioelectrical state in the plane $\mathrm{R}-\mathrm{Xc}(\mathrm{R} / \mathrm{H}-\mathrm{Xc} / \mathrm{H})$. The Cuban experience suggests that the simultaneous analysis of these two bioelectrical parameters is a necessary but not sufficient condition to absolutely differentiate one cancer patient from another or patients with any pathology from a population of apparently healthy subjects [30, 62]. This statement may be argued because cancer patients and apparently healthy individuals are inside 50 and $75 \%$ tolerance ellipses. Some of these patients evolve unfavorably during and after the application of chemotherapy. Nevertheless, other cancer patients out $95 \%$ tolerance ellipse $\left(3.5<\theta_{p} \leq 5\right)$ evolve favorably after this therapy [62]. Additionally, similar results are observed in lung cancer adult patients treated with surgery, radiotherapy, chemotherapy and/or immunotherapy (unpublished data). On the other hand, patients with acquired immune deficiency syndrome are also inside 50, 75 and $90 \%$ tolerance ellipses. In addition, there are no significant differences in body bioelectric parameters and body composition of these patients compared with those of an apparently healthy individual population [63].

The above-mentioned is why $d_{p r}$ is proposed in this study. $d_{p r}$ does not contradict $|Z|$ or $\theta$, but they complement each other. It should be expected that there is a minimum value of $d_{p r}$, from which a sick subject can be differentiated from an apparently healthy subject, although the patient is in any position inside the ellipse $95 \%$ tolerance ellipse. Other distance criteria for $d_{p r}$ may 
be used, such as Mahalanobis distance [22] or a Hausdorff distance [64]. For instance, Hausdorff distance may be suggested to calculate this minimum distance. A longitudinal study is required to know this minimum value of $\mathrm{d}_{\mathrm{pr}}$.

From bivariate statistics, it is well known that tolerance ellipses can be applied if $\mathrm{R}$ and $\mathrm{Xc}(\mathrm{R} / \mathrm{H}$ and $\mathrm{Xc} / \mathrm{H})$ are strongly correlated $(r \geq 0.8)[23,31]$. The values of $r$ show in Table 1 are less than 0.8 (correlation strength between moderate and fair). Rigorously speaking, the tolerance region should not be an ellipse but a rectangle in this $\mathrm{R}-\mathrm{Xc}(\mathrm{R} / \mathrm{H}-\mathrm{Xc} / \mathrm{H})$ plot, in agreement with [23]. This and the low correlations of $r^{\prime \prime}$ (fair-poor) among $R_{p}$, $\mathrm{Xc}_{\mathrm{p}}$ and $\theta_{\mathrm{p}}\left((\mathrm{R} / \mathrm{H})_{\mathrm{p}},(\mathrm{Xc} / \mathrm{H})_{\mathrm{p}}\right.$ and $\left.\theta_{\mathrm{p}}\right)$ are why the rectangular tolerance region is used in this study. Rectangular tolerance region has been used in other studies [6567]. In some studies, elliptical and rectangular tolerance regions are simultaneously analyzed [68, 69]. Additionally, the representation of multiple rectangles in the same $\mathrm{XY}$ plane is possible taking into account the work published by Wald [70].

As ellipse tolerance and rectangular tolerance regions (95\%) are the same and the rectangle and the ellipse are both centered at the same point, an ellipse can be inscribed in a rectangle [24]. In this case, it is easy to demonstrate that the ratio of the area of the rectangle/ area of the ellipse is 1.27 and the difference between their respective areas is $0.21 \mathrm{~L}_{1} \mathrm{~L}_{2}$. As a result, both areas are approximately equal. $\mathrm{L}_{1}\left(\mathrm{~L}_{1}=2 \mathrm{a}_{1}\right)$ and $\mathrm{L}_{2}\left(\mathrm{~L}_{2}=2 \mathrm{a}_{2}\right)$ are the length and width of the rectangle, respectively. The variable $a_{1}$ is the length of the semi-major axis of the ellipse whereas $a_{2}$ is the length of the semi-minor axis. $\mathrm{L}_{1}=2 \mathrm{a}_{1}$ and $\mathrm{L}_{2}=2 \mathrm{a}_{2}$ guarantee the biggest area of an ellipse within a rectangle.

Unlike the studies reported in this area of knowledge, the body bioelectric state of each cancer patient is individually represented in this study. This will permit an individualized integral diagnosis and the proposal of a personalized therapy for each of them. In addition, the analysis on animals or humans is suggested individually in a previous study [71]. Therefore, each cancer patient is represented in the $\mathrm{Xc} / \mathrm{H}$ versus $\mathrm{R} / \mathrm{H}$ plot, according to its age and gender.

Our results suggest performing a longitudinal study that permits to know how bioelectrical and physiological parameters of these patients with $\mathrm{Ts} / \mathrm{Tns}$ change over time and what relationships can be established between them. This longitudinal study will allow to establish prognostic indicators of the possible evolution of a cancer patient under the application of a therapeutic scheme.

\section{Conclusions}

In conclusion, the BIA is feasible to individualize body bioelectrical parameters and body bioelectric state in newly diagnosed cancer children and how differ from those in apparently healthy subjects, for the same age group and gender. Additionally, the tumor electrical properties may have a noticeable role in changes of body bioelectric-physiological parameters of these newly diagnosed cancer children.

\section{Abbreviations}

BIA: Bioelectric impedance analysis; R: Body electrical resistance; Xc: Body capacitive electrical reactance; |Z|: Body electrical impedance modulus; $\theta$ : Body phase angle; $\mathrm{H}$ : Height of the subject; R/H: Body electrical resistance per unit of height; $\mathrm{XC} / \mathrm{H}$ : Body capacitive electrical reactance per unit of height; USA: United State of America; BIVA: Bioelectrical impedance vector analysis; $r^{*}$ : Correlation coefficient of Pearson; Ts: Solid tumor; Tns: Non-solid tumor; Kg: Kilogram; $\mathrm{cm}$ : Centimeter; ${ }^{\circ}$ : Grade; \%: Percentage; (R/H)r: Average value of $\mathrm{R} / \mathrm{H}$ for the reference population; $(\mathrm{R} / \mathrm{H})_{\mathrm{p}}$ : Individual value of $\mathrm{R} / \mathrm{H}$ for the cancer patient; $\left(X_{C} / H\right)$ : : Average value of $\mathrm{X} C / \mathrm{H}$ for the reference population; $(\mathrm{XC} / \mathrm{H})_{\mathrm{p}}$ : Individual value of $\mathrm{XC} / \mathrm{H}$ for the cancer patient; $\left((\mathrm{R} / \mathrm{H})_{\mathrm{r}}\right.$ $\left.(\mathrm{X} / \mathrm{H})_{\mathrm{r}}\right)$ : Central point of the reference rectangle; $\left((\mathrm{R} / \mathrm{H})_{\mathrm{p},}\left(\mathrm{XC}_{\mathrm{C}}\right.\right.$

$\left.H)_{p}\right)$ : Bioelectrical state of any cancer child for each gender and age group; $d_{p r}$ Euclidean distance between two points $\left((R / H)_{p},\left(X_{C} / H\right)_{p}\right)$ and $\left((R / H)_{r},\left(X_{C} /\right.\right.$ $\left.H)_{r}\right) ; \vec{Z}_{r}$ : Position impedance vector of $\left((\mathrm{R} / \mathrm{H})_{r}(\mathrm{XC} / \mathrm{H})_{r}\right)$ referred to coordinate origin $(0,0) ; \vec{Z}_{r}$ : Modulus of $\vec{Z}_{r} ; \vec{Z}_{p}$ : Position impedance vector of $\left((\mathrm{R} / \mathrm{H})_{\mathrm{p}}\right.$ $\left.(X C / H)_{p}\right)$ referred to coordinate origin $(0,0) ; \vec{Z}_{p}$ : Modulus of $\vec{Z}_{p} ; \theta_{r}$ : Angle between $\vec{Z}_{r}$ and $x$-axis (represented by $\left.R / H\right) ; i \theta_{p}$ : Angle between $\vec{Z}_{p}$ and $x-$ axis (represented by $R / H)$; $R_{r}$ : Reference rectangle for body bioelectric states; $R_{r c}: R_{r}$ delimited with a continuous line; $R_{r d}: R_{r}$ delimited with dashed line; $X_{c_{p}}$ : Body capacitive electrical reactance of the patient; $X_{c_{t}}$ : Net capacitive electrical reactance of the tumor; $X_{c_{0}}$ : Total capacitive electrical reactance of healthy tissue (surrounding and away from the tumor); $\mathrm{X}_{\mathrm{C}_{\mathrm{o}-\mathrm{t}} \text { : Global }}$ capacitive electrical reactance of the tumor surrounding healthy tissue interface; C: Electrical capacity of the biological tissue under consideration; f: Working frequency $(50 \mathrm{kHz}) ; \mathrm{C}_{\mathrm{p}}$ : Body electrical capacity of the patient; $C_{t}$ : Net electrical capacity of the tumor; $C_{0}$ : Total electrical capacity of the healthy tissue (surrounding and away from the tumor); $C_{\text {o-t: }}$ Overall electrical capacity of the surrounding healthy tissue-tumor interface; $L_{1}$ : Length of the rectangle; $L_{2}$ : Width of the rectangle

\section{Acknowledgements}

We appreciate helpful questions and comments of the Editor in Chief and unknown reviewers that improve our manuscript. The authors thank the valuable help of Mario Hechevarria Sánchez, Larisa Zamora Matamoros, Juan Barrera Chacón, Yenia Infantes and nurses of the Oncology and Hematology Service of the hospital Infantil Sur Antonio María Béguez César. Additionally, we would like to thank Ing. Antonio Gómez Yépez (Grupo de Terapia Metabólica, Veracruz, México), who provided the Bodystat 1500-MDD BIA analyzer.

\section{Authors' contributions}

MMG, MVJ, TRG, SCAB, JCCR and LEBC participated in study concepts. TTBL, MMG, MVJ, TRG, SCAB, ARSC, JCCR, VGSG and LEBC designed the study. MMG, MVJ, TRG and JCCR participated in data acquisition. TTBL, MMG, ARSC and $L E B C$ participated in quality control of data and algorithms. TTBL, MMG, MVJ, TRG, SCAB, ARSC, JCCR, VGSG and LEBC analysed and interpreted the data. TTBL, ARSC and LEBC participated in statistical analysis. TTBL, MMG, MVJ, TRG, SCAB, ARSC, JCCR, VGSG and LEBC drafted the manuscript. MMG and LEBC edited the manuscript. MMG, MVJ, TRG, SCAB, ARSC, JCCR, VGSG and $L E B C$ revised the manuscript and supervised the entire work. The authors read, reviewed and approved the final manuscript.

\section{Funding}

This work is financially supported by the Universidad de Oriente, Santiago de Cuba, Cuba, under the grants \# 7227 and 7228, Cuba. In addition, Universidad de Santo Domingo, Dominican Republic, will support the payment of this manuscript once approved. The data of this study belongs to the Universidad de Oriente. This financial support is not used in the design of this protocol, the collection, analysis and/or interpretation of data, as well as in writing of this manuscript. Authors do no received direct funding. Additionally, there is not external funding source. In addition, 
Facultad de Ciencias de la Universidad Autónoma de Santo Domingo, Dominican Republic, covers the cost of this manuscript.

\section{Availability of data and materials}

Original data appear explicitly in Table 2. Nevertheless, any information and additional data available on request to the corresponding author (berguesc@yahoo.com).

\section{Ethics approval and consent to participate}

The final protocol was approved by the Ethics committee (Current Controlled trials BIACANCER12032009, 12 March 2009) and Scientific Board of the hospital Infantil Sur Antonio María Béquez César, Santiago de Cuba. Written Informed Consent is obtained from each participant before entering the trial.

\section{Consent for publication}

Not applicable.

\section{Competing interests}

The authors declare that they have no competing interests. Author Victoriano Gustavo Sierra González was employed by the company Grupo de las Industrias Biotecnológica y Farmacéuticas (BioCubaFarma, La Habana, Cuba). The remaining authors declare that the research was conducted in the absence of any commercial or financial relationships that could be construed as a potential conflict of interest.

\section{Author details}

'Departamento de Ciencias, Escuela de Física, Universidad Autónoma de Santo Domingo (UASD), Recinto Nagua, República Dominicana. ${ }^{2}$ Técnica Regional del Ministerio de Educación, Nagua, República Dominicana. ${ }^{3}$ Departamento de Farmacia, Facultad de Ciencias Naturales y Exactas, Universidad de Oriente, 90500 Santiago de Cuba, Cuba. ${ }^{4}$ Servicio de Oncología y Hematología del Hospital Infantil Sur Antonio María Béguez César, 90300 Santiago de Cuba, Cuba. ${ }^{5}$ Dirección Municipal de Salud Pública, 90500 Santiago de Cuba, Cuba. ${ }^{6}$ Ensayos Clínicos del Hospital Provincial Saturnino Lora, 90500 Santiago de Cuba, Cuba. ${ }^{7}$ Departamento de Telecomunicaciones, Facultad de Ingeniería Telecomunicaciones, Informática y Biomédicas, Universidad de Oriente, 90400 Santiago de Cuba, Cuba. ${ }^{8}$ Servicio de Neumología del Hospital Clínico Quirúrgico Juan Bruno Zayas, 90600 Santiago de Cuba, Cuba. ${ }^{9}$ Grupo de las Industrias Biotecnológica y Farmacéuticas, Avenida Independencia, No. 8126 Esquina a Calle 100, Boyeros, La Habana, Cuba. ${ }^{10}$ Departamento de Investigaciones, Centro Nacional de Electromagnetismo Aplicado, Universidad de Oriente, Ave. Las Américas s/n, 90400 Santiago de Cuba, Cuba.

\section{Received: 2 April 2020 Accepted: 9 June 2020}

\section{Published online: 13 June 2020}

\section{References}

1. Estadísticas de la Organización Mundial de la Salud. Cáncer nota descriptiva no 297; 2017. Available from: http://www.who.int/mediacentre/factsheets/ fs297/es/.

2. Salud y Asistencia Social. En Oficina Nacional de Estadística e Información (ONEI). Cuba: Edición 2017, Ministerio de Salud Pública, La Habana; 2019. Available from: http://www.one.cu/aec2016/19SaludPública.pdf/.

3. González Gilart G, Gainza SLS, Querol Betancourt N, Jiménez Portuondo N, Sell Lluveras M. Características clínico epidemiológicas de las leucemias en el niño. Medisan. 2011;15(12):1714-9 Available from: http://scielo.sld.cu/ scielo.php?script=sci_arttext\&pid=S1029-30192011001200005.

4. Verdecia Cañizares. Cáncer pediátrico en Cuba. Rev Cubana Pediatr. 2017; 89(1):1-3 Available from: http://www.medigraphic.com/pdfs/revcubped/ cup-2017/cup171a.pdf

5. Corrias A, Einaudi S, Chiorboli E, Weber G, Crino A, Andreo M, et al. Accuracy of fine needle aspiration biopsy of thyroid nodules in detecting malignancy in childhood: comparison with conventional clinical, laboratory, and imaging approaches. J Clin Endocrinol Metab. 2001;86(10):4644-8. https://doi.org/10.1210/jcem.86.10.7950.

6. Hu G, Li X, He B. Imaging biological tissues with electrical conductivity contrast below $1 \mathrm{Sm}^{-1}$ by means of magnetoacoustic tomography with magnetic induction. Appl Phys Lett. 2010;97(10):103705 Available from: http://www.ncbi.nlm.nih.gov/pmc/articles/PMC2951991/.
7. Brantlov S, Ward LC, Jødal L, Rittig S, Lange A. Critical factors and their impact on bioelectrical impedance analysis in children: a review. J Med Eng Technol. 2017;41(1):22-35. https://doi.org/10.1080/03091902.2016.1209590.

8. Piccoli A, Nescolarde LD, Rosell J. Análisis convencional y vectorial de bioimpedancia en la práctica clínica. Nefrología. 2002;22(3):228-38 Available from: http://www.revistanefrologia.com/es-pdf-X0211699502014897.

9. Matias CN, Santos DA, Júdice PB, Magalhães JP, Minderico CS, Fields DA, et al. Estimation of total body water and extracellular water with bioimpedance in athletes: a need for athlete-specific prediction models. Clin Nutr. 2016;35(2):468-74. https://doi.org/10.1016/j.clnu.2015.03.013.

10. Heyward VH. Practical body composition assessment for children, adults, and older adults. Int J Sport Nutr. 1998;8(3):285-307. https://doi.org/10.1123/ ijsn.8.3.285/.

11. Jemaa HB, Mankaï A, Khlifi S, Minaoui R, Ghozzi D, Zediri M, et al. Development and validation of impedance-based equations for the prediction of total body water and fat-free mass in children aged 8-11 years. Clin Nutr. 2019;38(1):227-33. https://doi.org/10.1016/j.clnu.2018.01.028.

12. Bellafronte NT, Batistuti MR, dos Santos NZ, Holland H, Romão EA, Chiarello PG. Estimation of body composition and water data depends on the bioelectrical impedance device. J Electr Bioimped. 2018;9(1):96-105. https:// doi.org/10.2478/joeb-2018-0014.

13. Maddocks M, Kon SS, Jones SE, Canavan JL, Nolan CM, Higginson IJ, et al. Bioelectrical impedance phase angle relates to function, disease severity and prognosis in stable chronic obstructive pulmonary disease. Clin Nutr. 2015;34(6):1245-50 Available from: http://www.bodystat.com/wp-content/ uploads/2018/04/110-NEW-Phase-angle-and-COPD-full-paper.pdf.

14. Farias CLA, Campos DJ, Bonfin CMS, Vilela RM. Phase angle from BIA as a prognostic and nutritional status tool for children and adolescents undergoing hematopoietic stem cell transplantation. Clin Nutr. 2013;32(3): 420-5. https://doi.org/10.1016/j.clnu.2012.09.003.

15. Visser M, van Venrooij LMW, Wanders DCM, de Vos R, Wisselink W, van Leeuwen PAM, et al. The bioelectrical impedance phase angle as an indicator of undernutrition and adverse clinical outcome in cardiac surgical patients. Clin Nutr. 2012;31(6):981-6 Available from: http://research.vumc.nl/ ws/portalfiles/portal/454579/hoofdstuk+4.pdf.

16. Nescolarde L, Núñez A, Bogónez-Franco P, Lara A, Vaillant G, Morales $R$, et al. Reference values of the bioimpedance vector components in a Caribbean population. e-SPEN J. 2013;8(4):e141-4 Available from: http:// upcommons.upc.edu/bitstream/handle/2117/19969/Reference\%20values\%2 0of\%20the\%20bioimpedance\%20vector\%20components\%20in\%20a\%2 OCaribbean\%20population.pdf.

17. Espinosa-Cuevas MDLÁ, Hivas-Rodripuez L, González-Medina EC, AtilanoCarsi X, Miranda-Alatriste P, Correa-Rotter R. Vectores de impedancia bioeléctrica Para la composición corporal en población mexicana. Rev Invest Clin. 2007;59(1):15-24 Available from: http://www.medigraphic.com/ pdfs/revinvcli/nn-2007/nn071c.pdf.

18. Lafargue AL, Cabrales LEB, Jarque MV, Martínez YL, Díaz YO. Parámetros bioeléctricos in vitro e in vivo, estimados con los analizadores Bodystat ${ }^{\oplus}$ 1500-MDD y BioScan ${ }^{\otimes}$ 98. Medisan. 2013;17(9):4054-63 Available from: http://scielo.sld.cu/scielo.php?script=sci_arttext\&pid=S1029-30192013 000900001.

19. Genton L, Herrmann FR, Spörri A, Graf CE. Association of mortality and phase angle measured by different bioelectrical impedance analysis (BIA) devices. Clin Nutr. 2018;37(3):1066-9 Available from: http://boris.unibe.ch/1 01319/7/Genton\%20ClinNutr\%202017_postprint.pdf.

20. Ward LC. Inter-instrument comparison of bioimpedance spectroscopic analysers. Open Med Dev J. 2009;1:3-10 Available from: http:// benthamopen.com/contents/pdf/TOMDJ/TOMDJ-1-3.pdf.

21. González MM, Jarque MV, González TR, Cabrales LEB, Lafargue AL, Tassé JPM. Influencia de la Resistencia eléctrica en la estimación del agua corporal total y la masa libre de grasa. Medisan. 2013;17(10):7001-10 Available from: http://www.medigraphic.com/pdfs/medisan/mds-2013/mds1310l.pdf.

22. Cabrales IB, González MM, Cabrales LEB, Jarque MV, Tassé JPM. Validez de las ecuaciones de estimación Para la masa libre de grasa por el método de la impedancia bioeléctrica en cualquier población. Medisan. 2016;20(12): 6055-62 Available from: http://scielo.sld.cu/scielo.php?script=sci_ arttext\&pid=S1029-30192016001200008.

23. Rencher AC. Methods of multivariate analysis. 2nd ed. New York: Wiley Interscience, A John Wiley \& Sons. Inc. Publication; 2002. p. 43-155. Available from: http://www.umpalangkaraya.ac.id/perpustakaan/digilib/files/ disk1/18/123-dfadf-alvincrenc-870-1-method_o-s.pdf. 
24. Wang FK, Hubele NF, Lawrence FP, Miskulin JD, Shahriari H. Comparison of three multivariate process capability indices. J Qual Technol. 2000;32(3):26375 Available from: http://www.researchgate.net/profile/Fu_Kwun_Wang/ publication/279972249_Comparison_of_Three_Multivariate_Process_ Capability_Indices/links/55cd51e108aebd6b88e05fde/Comparison-of-ThreeMultivariate-Process-Capability-Indices.pdf.

25. Rau GJ, Fassuliotis G. Equal-frequency tolerance ellipses for population studies of Belonolaimus longicaudatus. J Nematol. 1970:2(1):84 Available from: http://www.ncbi.n/m.nih.gov/pmc/articles/PMC2618713/pdf/84.pdf.

26. Piccoli A, Rossi B, Pillon L, Bucciante G. A new method for monitoring body fluid variation by bioimpedance analysis: the RXc graph. Kidney Int. 1994; 46(2):534-9 Available from: http://core.ac.uk/download/pdf/82530248.pdf.

27. Piccoli A, Nigrelli S, Caberlotto A, Bottazzo S, Rossi B, Pillon L, et al. Bivariate normal values of the bioelectrical impedance vector in adult and elderly populations. Am J Clin Nutr. 1995;61(2):269-70 Available from: http://s3. amazonaws.com/academia.edu.documents/42442276/Piccoli_A_Nigrelli_S_ Caberlotto A et al.20160208-28293-1472180.pdf?response-contentdisposition=inline\%3B\%20filename\%3DPiccoli_A_Nigrelli_S_Caberlotto_A_ et al..pdf\&X-Amz-Algorithm=AWS4-HMAC-SHA256\&X-Amz-Credential= AKIAIWOWYYGZ2Y53UL3A\%2F20200318\%2Fus-east-1\%2Fs3\%2Faws4_ request \&X-Amz-Date $=20200318 T 143125 Z \& X-A m z-$ Expires $=3600 \& X-A m z-$ SignedHeaders $=$ host $\& X-A m z-$ Signature $=e 034 f f 12 d 400 \mathrm{da} 55 \mathrm{a} 7255 \mathrm{fb} 2$ 08ea5115fcf21236063c60dea0d889168ee80ef9.

28. Piccoli A, Pittoni G, Facco E, Favaro E, Pillon L. Relationship between central venous pressure and bioimpedance vector analysis in critically ill patients. Crit Care Med. 2000;28(1):132-7 Available from: http://www.mikropolis.pl/_ pdf/biva_venouspresspccl.pdf.

29. Castizo-Olier J, Carrasco-Marginet M, Roy A, Chaverri D, Iglesias X, PérezChirinos C, et al. Bioelectrical impedance vector analysis (BIVA) and body mass changes in an ultra-endurance triathlon event. J Sports Sci Med. 2018; 17(4):571 Available from: http://www.ncbi.nlm.nih.gov/pmc/articles/ PMC6243631/.

30. Lafargue AL. Introduction of inductive elements in the Cole-Fricke-Cole model to describe the behavior of low frequency bioelectric parameters: experimental data and simulationsMaster thesis. Universidad de Oriente, Centro Nacional de Electromagnetismo Aplicado, Santiago de Cuba, Cuba; 2005.

31. Akoglu H. User's guide to correlation coefficients. Turk J Emerg Med. 2018; 18:91-3. https://doi.org/10.1016/j.tjem.2018.08.001.

32. Shime N, Ashida H, Chihara E, Kageyama K, Katoh Y, Yamagishi M, et al. Bioelectrical impedance analysis for assessment of severity of illness in pediatric patients after heart surgery. Crit Care Med. 2002;30(3):518-20. https://doi.org/10.1097/00003246-200203000-00004.

33. Brinksma A, Roodbol PF, Sulkers E, Kamps WA, de Bont ES, Boot AM, et al. Changes in nutritional status in childhood cancer patients: a prospective cohort study. Clin Nutr. 2015;34(1):66-73. https://doi.org/10.1016/j.clnu.2014. 01.013.

34. Kyle UG, Earthman CP, Pichard C, Coss-Bu JA. Body composition during growth in children: limitations and perspectives of bioelectrical impedance analysis. Eur J Clin Nutr. 2015;69(12):1298. https://doi.org/10.1038/ejcn.2015.8.

35. Azevedo ZMA, Moore DCBC, de Matos FAA, Fonseca VM, Peixoto MVM, Gaspar-Elsas MIC, et al. Bioelectrical impedance parameters in critically ill children: importance of reactance and resistance. Clin Nutr. 2013;32(5):8249. https://doi.org/10.1016/j.clnu.2013.01.011.

36. Williams JR. The declaration of Helsikin and public health. Bull World Health Organ. 2008;86(8):650-2 Available from: http://www.ncbi.nlm.nih.gov/pmc/ articles/PMC2649471/.

37. NIH Consensus statement. Bioelectrical impedance analysis in body composition measurement. NIH Technol Assess Statement. 1994:1-35 December 12-14. Available from: http://ci.nii.ac.jp/naid/10007076316/.

38. Steliarova-Foucher E, Colombet M, Ries LA, Moreno F, Dolya A, Bray F, et al. International incidence of childhood cancer, 2001-10: a population-based registry study. Lancet Oncol. 2017;18(6):719-31. https://doi.org/10.1016/ S1470-2045(17)30186-9.

39. Gupta S, Howard SC, Hunger SP, Antillon FG, Metzger ML, Israels T, et al. Treating childhood cancer in low-and middle-income countries. In: Jamison DT, Nugent R, Gelband H, Horton S, Jha P, Laxminarayan R, editors. Disease control priorities. 3rd ed. Washington: Editorial International Bank for Reconstruction and Development, World Bank Group; 2015. p. 121-46. Available from: http://www.ncbi.nlm.nih.gov/books/NBK343628/pdf/ Bookshelf_NBK343628.pdf.
40. Bravo LE, García LS, Collazos P, Aristizabal P, Ramirez O. Descriptive epidemiology of childhood cancer in Cali: Colombia 1977-2011. Colo Med. 2013;44(3):155 Available from: http://www.ncbi.nlm.nih.gov/pmc/articles/ PMC4002030/.

41. Toquica CDPV, Silva PAM, Acero H. Caracterización clínico-epidemiológica de los pacientes pediátricos con leucemias agudas en la Clínica Universitaria Colombia. Serie de casos 2011-2014. Pediatría. 2016;49(1):17-22. https://doi. org/10.1016/j.rcpe.2016.01.002.

42. Gupta D, Lammersfeld CA, Vashi PG, King J, Dahlk SL, Grutsch JF, et al. Bioelectrical impedance phase angle in clinical practice: implications for prognosis in stage IIIB and IV non-small cell lung cancer. BMC Cancer. 2009; 9(1):37. https://doi.org/10.1186/1471-2407-9-37.

43. Hui D, Bansal S, Morgado M, Dev R, Chisholm G, Bruera E. Phase angle for prognostication of survival in patients with advanced cancer: preliminary findings. Cancer. 2014;120(14):2207-14. https://doi.org/10.1002/cncr.28624

44. Lukaski HC, Kyle UG, Kondrup J. Assessment of adult malnutrition and prognosis with bioelectrical impedance analysis: phase angle and impedance ratio. Curr Opin Clin Nutr Metab Care. 2017;20:330-9. https://doi. org/10.1097/MCO.0000000000000387.

45. Lafargue $A L$, Cabrales LB, Larramendi RM. Bioelectrical parameters of the whole human body obtained through bioelectrical impedance analysis. Bioelectromagnetics. 2002;23(6):450-4. https://doi.org/10.1002/bem.10034.

46. Kimura S, Morimoto T, Uyama T, Monden Y, Knouchi Y, Iritani T. Application of electrical impedance analysis for diagnosis of a pulmonary mass. Chest. 1994;105(6):1679-82. https://doi.org/10.1378/chest.105.6.1679.

47. Al Ahmad M, Al Natour Z, Mustafa F, Rizvi TA. Electrical characterization of normal and cancer cells. IEEE Access. 2018;6:25979-86. https://doi.org/10. 1109/ACCESS.2018.2830883.

48. Zhang F, Jin T, Hu Q, He P. Distinguishing skin cancer cells and normal cells using electrical impedance spectroscopy. J Electroanal Chem. 2018;823:5316. https://doi.org/10.1016/j.jelechem.2018.06.021

49. Ermolina I, Polevaya Y, Feldman Y, Ginzburg BZ, Schlesinger M. Study of normal and malignant white blood cells by time domain dielectric spectroscopy. IEEE T Dielect El In. 2001;8(2):253-61. https://doi.org/10.1109/ 94.919948.

50. Qiao G, Duan W, Chatwin C, Sinclair A, Wang W. Electrical properties of breast cancer cells from impedance measurement of cell suspensions. J Phys Conf Ser. 2010;224:012081. https://doi.org/10.1088/1742-6596/224/1/ 012081

51. Fricke $\mathrm{H}$, Morse $\mathrm{S}$. The electric capacity of tumors of the breast. J Cancer Res Ther. 1926;10(3):340-76. https://doi.org/10.1158/jcr.1926.340.

52. Bera TK. Bioelectrical impedance and the frequency dependent current conduction through biological tissues: a short review. IOP Conf Ser: Mater Sci Eng. 2018;331(1):012005. https://doi.org/10.1088/1757-899X/331/1/ 012005.

53. Haemmerich D, Schutt DJ, Wright AS, Webster JG, Mahvi DM. Electrical conductivity measurement of excised human metastatic liver tumours before and after thermal ablation. Physiol Meas. 2009;30(5):459. https://doi. org/10.1088/0967-3334/30/5/003.

54. Huang YJ, Hoffmann G, Wheeler B, Schiapparelli P, Quinones-Hinojosa A, Searson P. Cellular microenvironment modulates the galvanotaxis of brain tumor initiating cells. Sci Rep. 2016;6:21583. https://doi.org/10.1038/ srep21583.

55. Rianna C, Radmacher M. Influence of microenvironment topography and stiffness on the mechanics and motility of normal and cancer renal cells. Nanoscale. 2017;9(31):11222-30. https://doi.org/10.1039/C7NR02940C.

56. Hanahan D, Weinberg RA. Hallmarks of cancer: the next generation. Cell. 2011;144(5):646-74. https://doi.org/10.1016/j.cell.2011.02.013.

57. Haltiwanger S. The electrical properties of cancer cells; 2008. http://www. royalrife.com/haltiwanger1.pdf (2008).

58. Lukaski HC. Requirements for clinical use of bioelectrical impedance analysis (BIA). Ann N Y Acad Sci. 1999;873:72-6. https://doi.org/10.1111/j.1749-6632. 1999.tb09451.x.

59. Diouf A, Diongue O, Nde M, Idohou-Dossou N, Thiam M, Wade S. Validity of bioelectrical impedance analysis in predicting total body water and adiposity among Senegalese school-aged children. PLoS One. 2018;13(10): e0204486 Available from: http://www.ncbi.nlm.nih.gov/pmc/articles/PMC61 81292/.

60. De Santis MC, Porporato PE, Martini M, Morandi A. Signaling pathways regulating redox balance in cancer metabolism. Front Oncol. 2018;8:126. https://doi.org/10.3389/fonc.2018.00126. 
61. Long J, Zhang CJ, Zhu N, Du K, Yin YF, Tan X, et al. Lipid metabolism and carcinogenesis, cancer development. Am J Cancer Res. 2018;8(5):778 Available from: http://www.ncbi.nlm.nih.gov/pmc/articles/PMC5992506/.

62. de la Cruz-López AL. Bioelectric parameters measured in cancer children treated with chemotherapy: phase diagramsDiploma thesis. Universidad de Oriente, Facultad de Ingeniería Eléctrica, Departamento Ingeniería Biomédica, Santiago de Cuba, Cuba; 2012.

63. Montoya ACR, Bourón AIN, Lafargue AL, Larramendi RM, Saní VP, Suárez GV, et al. Comparación bioeléctrica y de composición corporal en portadores y casos SIDA. Medisan. 2007;11(3):1-5 Available from: http://www.redalyc.org/ pdf/3684/368444988009.pdf.

64. Elber $\mathrm{G}$, Grandine $\mathrm{T}$. Hausdorff and minimal distances between parametric free forms in $\Re^{2}$ and $\Re^{3}$. In: International conference on geometric modeling and processing. Berlin: Heidelberg, Springer; 2008. p. 191-204.

65. Filzmoser $\mathrm{P}$, Hron $\mathrm{K}$, Reimann C. The bivariate statistical analysis of environmental (compositional) data. Sci Total Environ. 2010;408(19):4230-8. https://doi.org/10.1016/j.scitotenv.2010.05.011.

66. Chen H. A multivariate process capability index over a rectangular solid tolerance zone. Stat Sin. 1994;4:749-58 Available from: http://www3.stat. sinica.edu.tw/statistica/oldpdf/a4n223.pdf.

67. Genz A. Numerical computation of rectangular bivariate and trivariate normal and t probabilities. Stat Comput. 2004;14(3):251-60. https://doi.org/ 10.1023/B:STCO.0000035304.20635.31.

68. Di Bucchianico A, Einmahl JH, Mushkudiani NA. Smallest nonparametric tolerance regions. Ann Stat. 2001:1320-43 Available from: https:// projecteuclid.org/download/pdf_1/euclid.aos/1013203456.

69. Shahriari $\mathrm{H}$, Abdollahzadeh $\mathrm{M}$. A new multivariate process capability vector. Qual Eng. 2009;21(3):290-9. https://doi.org/10.1080/08982110902873605.

70. Wald A. An extension of Wilks' method for setting tolerance limits. Ann Math Stat. 1943;14(1):45-55 Available from: https://projecteuclid.org/ download/pdf_1/euclid.aoms/1177731491.

71. González MM, Morales DF, Cabrales LEB, Pérez DJ, Montijano JI, Castañeda ARS, et al. Dose-response study for the highly aggressive and metastatic primary F3II mammary carcinoma under direct current. Bioelectromagnetics. 2018:39(6):460-75. https://doi.org/10.1002/bem.22132.

\section{Publisher's Note}

Springer Nature remains neutral with regard to jurisdictional claims in published maps and institutional affiliations.

Ready to submit your research? Choose BMC and benefit from:

- fast, convenient online submission

- thorough peer review by experienced researchers in your field

- rapid publication on acceptance

- support for research data, including large and complex data types

- gold Open Access which fosters wider collaboration and increased citations

- maximum visibility for your research: over $100 \mathrm{M}$ website views per year

At BMC, research is always in progress.

Learn more biomedcentral.com/submissions 